\title{
Influence of L. thermotolerans and S. cerevisiae Commercial Yeast Sequential Inoculation on Aroma Composition of Red Wines (Cv Trnjak, Babic, Blatina and Frankovka)
}

\author{
Ana-Marija Jagatić Korenika ${ }^{1}$ (D) Ivana Tomaz ${ }^{1,2, * \mathbb{C}}$, Darko Preiner ${ }^{1,2} \mathbb{D}^{\text {, }}$, Marina Lavrić ${ }^{3}$, Branimir Šimić $^{1}$ \\ and Ana Jeromel ${ }^{1}$ \\ 1 Department of Viticulture and Enology, Faculty of Agriculture, University of Zagreb, Svetošimunska 25, \\ 10000 Zagreb, Croatia; amjagatic@agr.hr (A.-M.J.K.); dpreiner@agr.hr (D.P.); \\ brane.harlem.simic@gmail.com (B.S..); amajdak@agr.hr (A.J.) \\ 2 Center of Excellence for Biodiversity and Molecular Plant Breeding, Faculty of Agriculture, \\ University of Zagreb, Svetošimunska 25, 10000 Zagreb, Croatia \\ 3 Department of Viticulture and Enology, Faculty of Agriculture and Food Technology, University of Mostar, \\ Biskupa Čule bb, 88000 Mostar, Bosnia and Herzegovina; marina_lavric@yahoo.com \\ * Correspondence: itomaz@agr.hr
}

Citation: Korenika, A.J.; Tomaz, I.; Preiner, D.; Lavrić, M.; Šimić, B.; Jeromel, A. Influence of

L. thermotolerans and S. cerevisiae

Commercial Yeast Sequential

Inoculation on Aroma Composition of Red Wines (Cv Trnjak, Babic,

Blatina and Frankovka). Fermentation 2021, 7, 4. https://doi.org/10.3390/ fermentation7010004

Received: 24 November 2020 Accepted: 28 December 2020 Published: 31 December 2020

Publisher's Note: MDPI stays neutral with regard to jurisdictional clai$\mathrm{ms}$ in published maps and institutional affiliations.

Copyright: (C) 2020 by the authors. Licensee MDPI, Basel, Switzerland. This article is an open access article distributed under the terms and conditions of the Creative Commons Attribution (CC BY) license (https:// creativecommons.org/licenses/by/ $4.0 /)$.

\begin{abstract}
Even though Saccharomyces cerevisiae starter cultures are still largely used nowadays, the non-Saccharomyces contribution is re-evaluated, showing positive enological characteristics. Among them, Lachancea thermotolerans is one of the key yeast species that are desired for their contribution to wine sensory characteristics. The main goal of this work was to explore the impact of L. thermotolerans commercial yeast strain used in sequential inoculation with $S$. cerevisiae commercial yeast on the main enological parameters and volatile aroma profile of Trnjak, Babić, Blatina, and Frankovka red wines and compare it with wines produced by the use of $S$. cerevisiae commercial yeast strain. In all sequential fermented wines, lactic acid concentrations were significantly higher, ranging from $0.20 \mathrm{mg} / \mathrm{L}$ in Trnjak up to $0.92 \mathrm{mg} / \mathrm{L}$ in Frankovka wines, while reducing alcohol levels from $0.1 \% v / v$ in Trnjak up to $0.9 \% v / v$ in Frankovka wines. Among volatile compounds, a significant increase of ethyl lactate and isobutyl acetate, geraniol, and geranyl acetate was detected in all wines made by use of $L$. thermotolerans. In Babić wines, the strongest influence of sequential fermentation was connected with higher total terpenes and total ester concentrations, while Trnjak sequentially fermented wines stood up with higher total aldehyde, volatile phenol, and total lactone concentrations. Control wines, regardless of variety, stood up with higher concentrations of total higher alcohols, especially isoamyl alcohol. The present work contributed to a better understanding of the fermentation possibilities of selected non-Saccharomyces strains in the overall red wine quality modeling.
\end{abstract}

Keywords: L. thermotolerans; volatile aroma compounds; red grape varieties

\section{Introduction}

Wine quality is influenced by many factors starting from the geographical origin of the grapes, varietal grape must composition, vinification process, and microbial activity of yeast species used. Wine is a complex mixture of chemical compounds that contribute differently to overall quality. Among them, volatile aroma compounds that can be divided according to their origin into varietal (grape) aromas, fermentative aromas, and aging aromas are some of the most important contributors to flavor perception. Between grape varieties, there is a notable sensory difference in aroma composition that is usually not really perceptible at pre-fermentative stages but strongly influenced by microbial activity during wine production [1]. Nowadays in winemaking, Saccharomyces cerevisiae commercial starter cultures are still largely used with the main goal being the assurance 
of more predictable and desired final wine quality results. However, some evidence suggests that the continuous use of commercial yeast can significantly reduce the variability of autochthonous yeasts as well as aromatic complexity and uniqueness of the wine [2,3]. In the last decade, the contribution and important role of non-Saccharomyces wine yeasts were re-evaluated in many works [2,4-7] showing positive enological characteristics that are more or less absent in S. cerevisiae. Among them, Lachancea thermotolerans is one of the key yeast species that is desired for their positive contribution to wine sensory characteristics [8]. According to Gobbi et al. [9], the association of L. thermotolerans and S. cerevisiae significantly reduced ethanol levels from 0.7 to $0.9 \% v / v$, especially when fermentation was carried out at lower temperatures. In the work by Binati et al. [7] the highest potential to reduce ethanol content was achieved by the use of L. thermotolerans strains. The possibility to increase lactic acid concentrations and at the same time reduce volatile acidity was confirmed by $[4,10]$, while increased production of 2-phenylethyl alcohol was described as a characteristic of L. thermotolerans by Beckner et al. [11]. The same authors noted significantly higher production of terpenes nerol and terpine-4-ol as well as 3-methylthio-1-propanol. A study evaluating the impact of several non-Saccharomyces yeasts in sequential inoculation with S. cerevisiae showed that an L. thermotolerans-S. cerevisiae combination had the most potential for increased chemical complexity of the Shiraz volatile profile [12]. In the work by Whitener et al. [13], L. thermotolerans fermentation showed a higher amount of acetate esters and certain terpenes but also the lowest amount of both total acidity and malic acid, which is in agreement with previous data that had indicated S. cerevisiae as a poor L-malate metabolizer compared to non-Saccharomyces yeasts. Nowadays, based on previously published results, commercial non-Saccharomyces starter cultures have been developed for use in wine production, but compared to S. cerevisae, little work has been done with commercial starter cultures that can point out what specific chemical profile to expect based on grape variety and overall fermentation conditions. The varieties Trnjak, Babić, and Blatina are native red grapevine varieties grown in the Dalmatia wine region (Croatia) used for the production of high-quality red wines. Typically, they have lower levels of total acidity and higher $\mathrm{pH}$ values in grape juice and wine, and this is especially expressed in years with extremely high temperatures. Frankovka (syn. Blaufraenkisch) is a variety mostly distributed in the continental part of Croatia and Istria but also in neighboring regions of Slovenia, Hungary, and Austria. Usually, it is used for the production of fresh and fruity red wines, which are also hard to obtain in years with elevated temperatures, which have become more and more frequent in the last decades. The aims of the present study were to explore the impact of the L. thermotolerans commercial yeast strain (Laktia, Lallemand Inc., Montreal, QC, Canada), used in sequential inoculation with $S$. cerevisiae commercial yeast (Uvaferm BDX, Lallemand Inc. Montreal, QC, Canada), on the main enological parameters and volatile aroma profiles of Trnjak, Babić, Blatina, and Frankovka red wines and to compare it with control wines produced by use of an S. cerevisiae commercial strain. The present work contributes to a better understanding of the fermentation possibilities of selected commercial non-Saccharomyces strains in overall red wine quality modeling.

\section{Materials and Methods}

\subsection{Yeast Strains}

The commercial S. cerevisiae and L. thermotolerans strains were provided from LallemandInc., Montreal, QC, Canada as active dry yeasts. Both yeast strains were precultured in the same grape must at $25^{\circ} \mathrm{C}$ for $72 \mathrm{~h}$. Each yeast strain was added at approximately $1 \times 10^{7}$ cells $/ \mathrm{mL}$, and fermentations were carried out at $20^{\circ} \mathrm{C}$ according to the manufacturer's instructions. The cell concentrations were determined by counting under a light microscope (Zeiss Axioscope2-Plus microscope (Carl Zeiss Ltd., Oberkochen, Germany). 


\subsection{Fermentation Trials}

Grape varieties Trnjak and Blatina were grown in the Mostar vineyard, Bosnia and Herzegovina, while the other two grape varieties were grown in Croatia, namely Babic in the Jadrtovac vineyard (located near Śibenik) and Frankovka in the experimental Jazbina vineyard (located in Zagreb). For each grape variety (Blatina, Trnjak, Babić, Frankovka), $150 \mathrm{~kg}$ of grapes harvested in 2019 was destemmed, crushed, and distributed evenly into three $50 \mathrm{~L}$ stainless steel fermenters. Basic chemical composition of the grapes was as follows: for Blatina, initial sugar $220 \mathrm{~g} / \mathrm{L}$, total acidity $6.05 \mathrm{~g} / \mathrm{L}$ as tartaric acid, yeast assimilable nitrogen $240 \mathrm{mg} / \mathrm{L}$, and $\mathrm{pH} 3.39$; for Trnjak, $205 \mathrm{~g} / \mathrm{L}$, total acidity $7.03 \mathrm{~g} / \mathrm{L}$ as tartaric acid, yeast assimilable nitrogen $270 \mathrm{mg} / \mathrm{L}$, and pH 3.52; for Babić, initial sugar $235 \mathrm{~g} / \mathrm{L}$, total acidity $7.60 \mathrm{~g} / \mathrm{L}$ as tartaric acid, yeast assimilable nitrogen $220 \mathrm{mg} / \mathrm{L}$, and pH 3.30; for Frankovka, initial sugar $230 \mathrm{~g} / \mathrm{L}$, total acidity $7.75 \mathrm{~g} / \mathrm{L}$ as tartaric acid, yeast assimilable nitrogen $245 \mathrm{mg} / \mathrm{L}$, and $\mathrm{pH}$ 3.32. In all variants, sulfur dioxide $\left(\mathrm{SO}_{2}\right)$, in a concentration of $50 \mathrm{mg} / \mathrm{L}$, was added to prevent oxidation and inhibit indigenous bacterial or fungal growth. The control variants were inoculated by S. cerevisiae Uvaferm BDX (control culture), while the sequential variants were inoculated with $L$. thermotolerans LAKTIA strain with the addition of the $S$. cerevisiae Uvaferm BDX after 2 days of fermentation. The maceration process, at $20^{\circ} \mathrm{C}$, lasted for 7 days, and during that period, mash aeration and cap management were carried out by mechanical mixing. Alcoholic fermentation finished by the end of the maceration process, and at that moment wines were separated from the pomace, and the solid pulp left behind was pressed by use of a hydropress (Lancman VS-A 80, Gomark d.o.o., Vransko, Slovenia). Free run wines and pressed wines were mixed. The course of fermentation was monitored by sugar consumption, and it was considered complete when the residual sugar concentrations were under $1.5 \mathrm{~g} / \mathrm{L}$. In all variants, fermentation started $24 \mathrm{~h}$ after inoculation and lasted between 10 and 12 days. In that period, fermentation kinetics was monitored by the decomposition of sugars showing no marked difference. The final wines were bottled in $750 \mathrm{~mL}$ glass bottles with screw caps and transported to the laboratory of the Department of Viticulture and Enology, Faculty of the Agriculture University of Zagreb, for chemical analysis.

\subsection{Physicochemical Analysis}

Basis wine parameters including alcohol content $(\%, v / v), \mathrm{pH}$ values, and total and volatile acidity were quantified applying methods recommended by the International Organization of Vine and Wine (OIV, 2016) [14].

\subsection{Organic Acids Analysis}

Analysis of individual acids (malic and lactic acid) was done by an Agilent Series 1100 HPLC system equipped with a diode array detector (Agilent, Palo Alto, CA, USA). In brief, the determination was performed isocratically with the flow rate set to $0.6 \mathrm{~mL} / \mathrm{min}$ with $0.065 \%$ phosphoric acid (p.a. Merck, Darmstadt, Germany) as a mobile phase. An Aminex HPX-87H column, $300 \times 7.8$ mm i.d. (Bio-Rad Laboratories, Hercules, CA, USA), was heated at $65^{\circ} \mathrm{C}$, while the detector was set to $210 \mathrm{~nm}$ [15].

\subsection{Volatile Compounds Determination}

Volatile compound analysis of wine samples was performed according to the described method [15]. Isolation of analytes was performed by solid-phase extraction (SPE) on LiChrolut EN cartridges ( $200 \mathrm{mg} / 3 \mathrm{~mL}$, Merck, Darmstadt, Germany). First, $50 \mathrm{~mL}$ of sample was loaded to the column that was previously conditioned by successive washing with $3 \mathrm{~mL}$ dichloromethane (UHPLC gradient grade J.T. Baker, Deventar, The Netherland), methanol (UHPLC gradient grade J.T. Baker, Deventar, The Netherland), and 13\% aqueous ethanol (LiChrosolv, Merck, Darmstadt, Germany) solution. After the passage of the sample through the column, residual sugars and other polar compounds were washed out with $3 \mathrm{~mL}$ of water. The column was dried by the passing of air. The evaluation of analytes was done by $1 \mathrm{~mL}$ of dichloromethane. As a quality control, $50 \mathrm{~mL}$ of water was loaded to the SPE 
column instead of the sample. Quantitative and qualitative analyses were performed on a Thermo Scientific Trace 1300 system coupled with ISQ 7000 mass spectrometer with a ZBWAX column $(60 \mathrm{~m} \times 0.32 \mathrm{~mm}$ i.d., with $0.5 \mu \mathrm{m}$ film thickness, Phenomenex, Torrance, CA, USA). The temperature program was as follows: $40^{\circ} \mathrm{C}$ for $15 \mathrm{~min}$, from 40 to $250^{\circ} \mathrm{C}$ with increments of $2{ }^{\circ} \mathrm{C}$ per minute, and $250{ }^{\circ} \mathrm{C}$ for $15 \mathrm{~min}$. The transfer line was set to $250{ }^{\circ} \mathrm{C}$, and the flow rate of helium was $1 \mathrm{~mL} / \mathrm{min}$. The MS was operated in electron ionization (EI) mode at $70 \mathrm{eV}$ with total ion current (TIC) monitoring. Identification was done by comparing retention times and mass spectra with those of standards. A list of used standards, linear retention indices, and other parameters for identification and quantification are presented in Supplementary Materials Table S1. Quantification was done by calibration curves. The curves (based on quantification ions) were constructed with Chromeleon ${ }^{\mathrm{TM}}$ Chromatography Data System (CDS) software. For all available standards (Table S1), six different concentrations were prepared. For two compounds (Terpendiol I and II) semi-quantitative analysis was performed. Their concentrations were expressed in equivalents of similar compounds, with the assumption that a response factor was equal to one.

\subsection{Determination of Odor Activity Values and Relative Odor Contributions}

Each chemical substance can have a specific influence on the wine aroma. It can be presented by the odor activity value (OAV) and relative odor contributions (ROCs). Thus, they can be used as a markers in determining the role of a specific compound in the sample aroma composition. OAV is calculated as the quotient of its concentration (c) and corresponding odor detection threshold $(\mathrm{t})$ reported in the literature [16]. Volatile aroma substances with an OAV $\geq 1$ can have a direct impact on aroma, and they are usually marked as one of the most significant volatile substances or the most active odors [17]. Volatiles with OAVs $<1$ can also positively influence the wine aroma complexity and aromatic intensity of other compounds through synergistic effects [18]. The ROC of each aroma compound is calculated as the ratio of the OAV of the respective compound to the total OAVs of each wine [19].

\subsection{Statistical Analysis}

Means and standard deviations were calculated for all parameters related to physicochemical properties of wines as well as for all the volatile organic compounds obtained after analyses. One-way ANOVA was performed for all parameters separately due to the significant differences among the four cultivars studied; to define common effects of $L$. thermotolerans yeast in sequential fermentation with $S$. cerevisiae against control wine, data for volatile organic compounds were standardized within cultivars using z-score normalization. One-way ANOVA and two-sided Dunnett test were performed using standardized data to compare the treatment (L. thermotolerans) with control for data from all four cultivars. The analysis was carried out with XLSTAT software v.2020.3.1. (Addinsoft, New York, NY, USA).

\section{Results and Discussion}

\subsection{Physicochemical Composition}

The results of basic physicochemical analysis of wines are presented in Table 1 showing that the use of $L$. thermotolerans yeast in sequential fermentation with $S$. cerevisiae can be used as one useful tool for alcohol content reduction in wines by the production of lactic acid, thus leading to biological acidification. Previous studies $[7,20]$ have already pointed out that the use of non-Saccharomyces yeasts can reduce the alcohol content of wine, which is in accordance with our data. Reducing alcohol levels ranged from $0.1 \% v / v$ in Trnjak wines up to $0.9 \% v / v$ in Frankovka wines. In the work by Sgouros et al. [21], the alcohol reduction by use of the high lactate-producing L. thermotolerans strain (P-HO1) in sequential inoculation with $S$. cerevisiae, produced the highest levels of lactic acid ever recorded in mixed fermentations $(10.4 \mathrm{~g} / \mathrm{L})$, increasing thereby the acidity and reducing ethanol by $1.6 \%$ vol. In our work, lactic acid concentrations were also significantly higher in all 
sequential fermented wines, not depending on variety, ranging from $0.20 \mathrm{mg} / \mathrm{L}$ in Trnjak wines up to $0.92 \mathrm{mg} / \mathrm{L}$ in Frankovka wines. Natural S. cerevisiae strains produce only traces of D-lactic acid during alcoholic fermentation, and levels between 100 and $500 \mathrm{mg} / \mathrm{L}$ have been reported in final wines [22]. Higher lactic acid concentrations had a positive effect on total acidity and $\mathrm{pH}$ values of sequential fermented wines, ensuring better wine stability as well as aging potential and overall quality. This is especially important nowadays with global climate change influencing grape composition and resulting in lower acidity and increasing sugar concentrations [23]. Volatile acidity is one of the important parameters influencing wine quality, and it is also strongly dependent on the type of yeast conducting alcoholic fermentation. In the past, non-Saccharomyces yeasts were considered undesired and one of the reasons was higher acetic acid production. Nowadays, published studies have generated highly variable results, showing that some of them can have desirable enological properties connected with low production of volatile acidity [4]. Among nonSaccharomyces yeasts, $L$. thermotolerans stood out as a low acetic acid producer, which has been shown in our work, with volatile acidity not differing compared to values achieved in fermentation conducted by $S$. cerevisiae commercial yeast. Differences observed in malic acid concentrations could be connected with the esterification process, resulting in diethyl malate presence (Table 1) or the weak but possible ability of $S$. cerevisiae to metabolize L-malic acid during wine fermentation [22].

Table 1. Physicochemical properties of Babić, Blatina, Frankovka, and Trnjak wines.

\begin{tabular}{|c|c|c|c|c|c|c|c|c|}
\hline & $\begin{array}{l}\text { Babić } \\
\text { Control }\end{array}$ & $\begin{array}{c}\text { Babić } \\
\text { Lachancea }\end{array}$ & $\begin{array}{l}\text { Blatina } \\
\text { Control }\end{array}$ & $\begin{array}{c}\text { Blatina } \\
\text { Lachancea }\end{array}$ & $\begin{array}{c}\text { Frankovka } \\
\text { Control }\end{array}$ & $\begin{array}{l}\text { Frankovka } \\
\text { Lachancea }\end{array}$ & $\begin{array}{l}\text { Trnjak } \\
\text { Control }\end{array}$ & $\begin{array}{c}\text { Trnjak } \\
\text { Lachancea }\end{array}$ \\
\hline \multicolumn{9}{|l|}{ Compounds } \\
\hline $\begin{array}{l}\text { Alcohol } \\
(\%, v / v)\end{array}$ & $13.7 \pm 0.1^{\mathrm{a}}$ & $13.0 \pm 0.0^{\mathrm{b}}$ & $12.9 \pm 0.0^{\mathrm{a}}$ & $12.5 \pm 0.0^{\mathrm{b}}$ & $13.5 \pm 0.0^{a}$ & $12.6 \pm 0.1^{b}$ & $11.8 \pm 0.0^{a}$ & $11.7 \pm 0.0^{a}$ \\
\hline $\begin{array}{l}\text { Total acidity } \\
\quad *(\mathrm{~g} / \mathrm{L})\end{array}$ & $6.60 \pm 0.04^{b}$ & $7.75 \pm 0.02^{a}$ & $5.33 \pm 0.05^{b}$ & $5.85 \pm 0.07^{\mathrm{a}}$ & $7.55 \pm 0.04^{b}$ & $\underset{\mathrm{a}}{10.10 \pm 0.02}$ & $4.82 \pm 0.03^{b}$ & $6.90 \pm 0.04^{a}$ \\
\hline $\begin{array}{l}\text { Volatile } \\
\text { acidity } \\
(\mathrm{g} / \mathrm{L})\end{array}$ & $0.47 \pm 0.01^{\mathrm{a}}$ & $0.50 \pm 0.00^{a}$ & $0.44 \pm 0.00^{\mathrm{a}}$ & $0.54 \pm 0.01^{b}$ & $0.64 \pm 0.00^{a}$ & $0.67 \pm 0.00^{a}$ & $0.37 \pm 0.00^{\mathrm{a}}$ & $0.35 \pm 0.01^{a}$ \\
\hline $\mathrm{pH}$ & $3.40 \pm 0.01^{a}$ & $3.33 \pm 0.00^{b}$ & $3.46 \pm 0.01^{a}$ & $3.35 \pm 0.00^{b}$ & $3.38 \pm 0.00^{a}$ & $3.30 \pm 0.00^{b}$ & $3.86 \pm 0.01^{a}$ & $3.76 \pm 0.01^{b}$ \\
\hline $\begin{array}{c}\text { Malic acid } \\
(\mathrm{g} / \mathrm{L})\end{array}$ & $0.79 \pm 0.05^{\mathrm{a}}$ & $0.62 \pm 0.03^{b}$ & $1.08 \pm 0.04^{\mathrm{a}}$ & $0.76 \pm 0.05^{b}$ & $0.75 \pm 0.01^{\mathrm{a}}$ & $0.50 \pm 0.03^{b}$ & $1.14 \pm 0.02^{\mathrm{a}}$ & $1.10 \pm 0.01^{\mathrm{a}}$ \\
\hline $\begin{array}{l}\text { Lactic acid } \\
\quad(\mathrm{g} / \mathrm{L})\end{array}$ & $0.16 \pm 0.02^{b}$ & $0.99 \pm 0.04^{a}$ & $0.09 \pm 0.05^{b}$ & $0.81 \pm 0.02^{\mathrm{a}}$ & $0.11 \pm 0.04^{b}$ & $1.09 \pm 0.01^{\mathrm{a}}$ & $0.12 \pm 0.02^{b}$ & $0.32 \pm 0.04^{\mathrm{a}}$ \\
\hline
\end{tabular}

* Tartaric acid and ** acetic acid equivalents. Concentrations expressed as mean \pm standard deviation $(n=3)$. Means with different superscript letters, for each variety separately, in the same row differ significantly $(p \leq 0.05)$.

\subsection{Volatile Compound Composition}

In Table 2 one hundred and twenty-one individual volatile compounds are presented, quantified, and classified into several chemical classes (aldehydes, higher alcohols, volatile phenols, terpenes, C13-norisoprenoids, lactones, esters, fatty acids, sulfur compounds, other compounds, other alcohols), showing significant difference among red wines produced by the use of pure $S$. cerevisiae commercial yeast and the combination of $L$. thermotolerans and S. cerevisiae commercial yeast within four cultivars. Significant varietal effects were obtained for the majority of volatile compounds except for trans-3-hexene-1-ol, tyrosol, 1,8-terpin, 8-hidroxylinalool, neralidol, menthol, $\beta$-ionone-5,6-epoxide, nonanoic acid, 1,4-butanediol, and acetoin. For this reason, standardized data were used to define the common effects of L. thermotolerans and S. cerevisiae on volatile compounds. In Figure 1, results of the two-sided Dunnett test using standardized data (z-scores) are presented only for volatile compounds with significant differences against the control for all cultivars. 


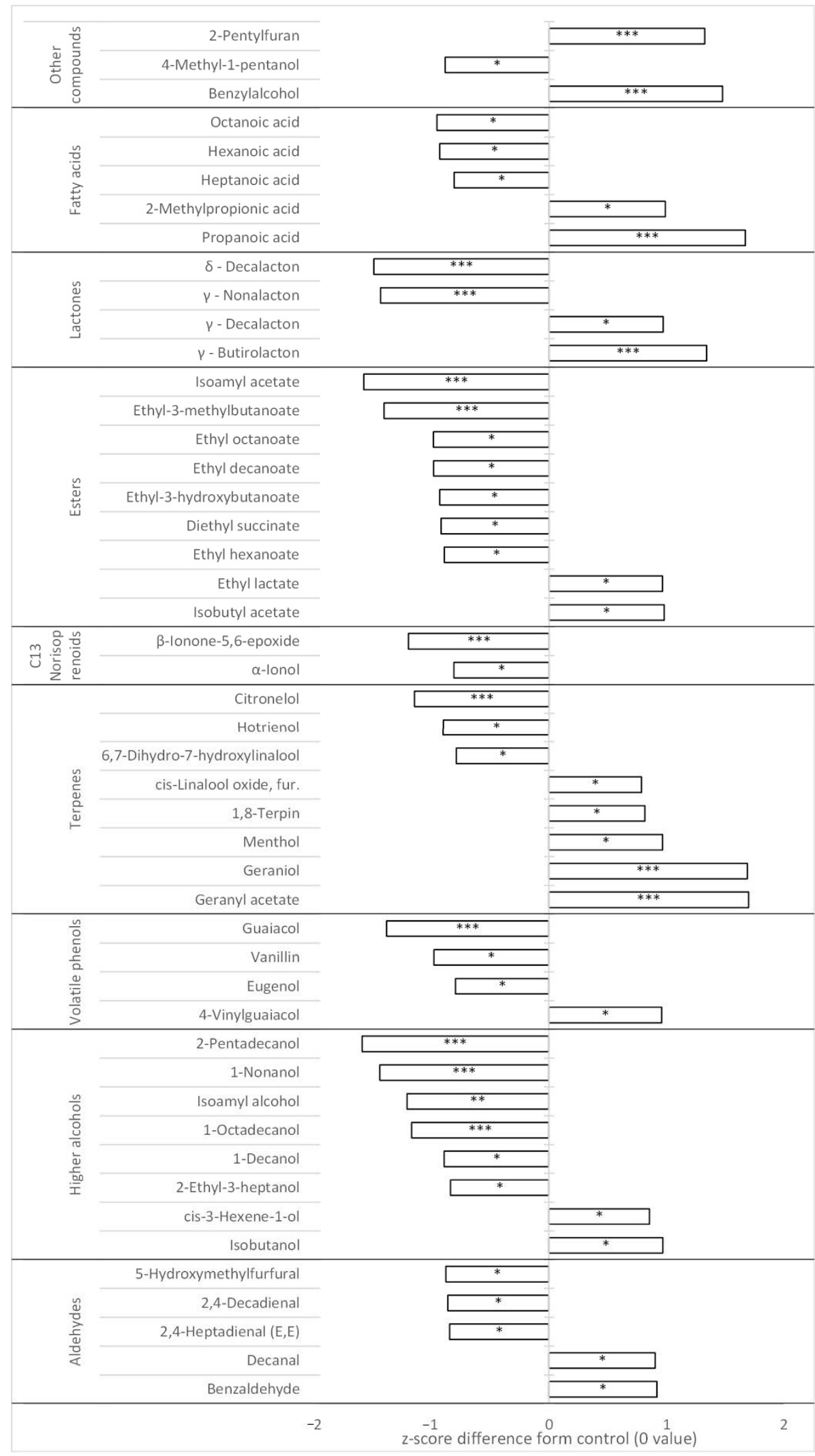

Figure 1. Common significant effects of L. thermotolerans yeast in sequential fermentation with S. cerevisiae against control wines expressed as the difference of z-score from control (presented as 0 value) for all four cultivars using z-score standardization within cultivars for volatile aroma compounds with significant effect only; significance level: ${ }^{*} p<0,05,{ }^{* *} p<0.01$ and ${ }^{* * *} p<0.001$ with two-sided Dunnett test. 


\subsubsection{Aldehydes}

Aldehyde concentration is connected with the degree of ripeness, treatments before fermentation, enzymatic oxidation, and breakdown of grape lipids, as well as variety. Comparing Babić, Blatina, Frankovka, and Trnjak total aldehydes concentrations, the highest ones were detected in Trnjak wines, while there were no marked differences between the others. Trnjak wines were also the only ones with a positive influence of sequential fermentation on total aldehyde concentration as well as 5-hydroxymethylfurfural and furfural concentrations. In order to protect themselves, yeasts reduce both furfural and HMF to their furyl acid or alcohol derivatives through NAD(P)H-dependent reductive pathways that utilize a range of aldehyde dehydrogenases involved in glycolysis and ethanol fermentation. Under aerobic conditions, S. cerevisiae transforms furfural to furoic acid, while under anaerobic fermentation, the primary product is furfuryl alcohol [24]. These detoxification processes lead to a lack of $\mathrm{NADH}$, suggesting that furfural reduction competes for NADH and results in a decrease in cell growth and ethanol formation $[25,26]$. Accordingly, L. thermotolerans may have a stronger ability to reduce these aldehydes, even though there was no significant difference in furfuryl alcohol production between control and sequential fermentation wines. Decanal, as the only individual aldehyde with OAV $>1$ in Blatina, Frankovka, and Trnjak wines produced with L. thermotolerans, was significantly higher compared to control wines with a notable odor contribution.

\subsubsection{C13-Norisoprenoids and Terpenes}

These two groups of chemical compounds primarily generate the varietal odor profile of wines that are characterized by floral and fruity aromas and are mainly translocated from the grape to the must during the crushing, pressing, and settling process in free volatile form or bound to sugars. Thus, higher enzymatic activity by the action of endogenous or exogenous glycosidase enzymes during the winemaking process can influence their release. Previous works [27-29] have shown those non-Saccharomyces yeasts and among them also certain strains of $L$. thermotolerans can have high $\beta$-glucosidase activity. Only in Babić wines was total terpene concentration significantly higher in sequentially fermented wines due to the higher concentrations of linalool, 8-hydroxylinalool, tetrahydrolinalool, farnesol, neral, geraniol, and geranyl acetate. Significantly higher concentrations of geraniol and geranyl acetate were present in all sequentially fermented variants, not depending on variety, which is in accordance with data published by Beckner Whitener et al. [13]. Farnesol has also been positively connected with L. thermotolerans activity [13], while in the work by Whitener et al. [12], linalool was indicated as a key compound in Shiraz wines with higher amounts in L. thermotolerans-S. cerevisiae sequential fermentation. In Blatina and Trnjak wines, no significant difference was detected in total terpene concentrations among variants, but among detected individual terpenes, the concentrations of 1,8-terpin stood up showing significantly higher concentrations in Blatina, Trnjak, and also Frankovka wine samples produced by sequential fermentation. Neral concentrations were higher in Babić and Blatina wines, while nerol was presented in higher concentrations in Frankovka and Trnjak sequential variants. Terpine-4-ol was also among compounds pointed out as one whose concentration can be influenced by L. thermotolerans activity [11]. Our data showed a significant increase in Blatina and Trnjak wines. Only in Frankovka control wines was total terpene concentration significantly higher compared to sequentially fermented wines, mainly due to the presence of linalool and citronellol, which showed higher ROCs (Table 2). In addition, as shown in Figure 1, significantly lower concentrations of citronellol were presented in all sequential fermentation wines compared to the control. Comparing total C13-norisoprenoids concentrations, no significant influence of $L$. thermotolerans yeast, not depending on variety, was noted, while only in Blatina control wines were higher concentrations of $\beta$-damascenone and TDN noted. 


\subsubsection{Higher Alcohols and Esters}

Among fermentation aroma compounds, higher alcohols and esters can be strongly influenced by the type of yeasts used and fermentation conditions [4]. The concentrations of higher alcohols not exceeding the amount of $300 \mathrm{mg} / \mathrm{L}$ can positively influence the formation of wine complexity [30], which was not the case in our samples. Slightly higher concentrations were present in Frankovka and Trnjak wines, mainly due to 2-methyl-1butanol content, but as can be seen from Table 2, with values under the odor detection threshold. In the analyzed red wines, total higher alcohol concentrations were significantly higher in control variants, except in Trnjak wines, where no marked differences were noted. There was a $13 \%$ lower total concentration of higher alcohols, with the greatest difference observed for isoamyl alcohol when $L$. thermotolerans was used, which was also reported by [20]. Gobbi et al. [9] also reported that in sequential inoculation, L. thermotolerans reduced isoamyl alcohol and isobutanol concentrations. In our work, isoamyl alcohol reduction was also noted in all sequential variants, not depending on variety, while isobutanol concentrations differed according to variety, with higher concentrations in Babić, Frankovka, and Trnjak sequentially fermented wines and lower in Blatina wines. Escribano et al. [31] pointed out L. thermotolerans as a top 1-propanol and 1-hexanol producing species when a pure culture was used, while in our study, results were different between varieties. In Babić wines, sequential fermentation positively influenced 1-hexanol concentrations, in Trnjak there were no differences, while in Blatina and Frankovka control wines, higher concentrations were present. Among all higher alcohols detected, only 1hexanol was above the OAV. Higher phenylethyl alcohol was detected in Babić and Trnjak sequentially produced wines, while in Blatina and Trnjak wines, higher concentrations were presented in control wines. Similar results were presented in the work by Comitini et al. [27], where just one of the L. thermotolerans strains tested showed a statistically significant difference in phenylethyl alcohol concentration, while Benito et al. [20] noted that between non-Saccharomyces yeasts tested, L. thermotolerans was the best producer of phenylethyl alcohol but with lower concentrations compared to fermentation by $S$. cerevisiae yeast. Chen et al. [32] observed in L. thermotolerans conducted fermentation a decrease of approximately $15 \mathrm{mg} / \mathrm{L}$ of phenylethyl alcohol compared to the wines produced with S. cerevisiae yeast, while no differences were detected for 2-phenylethyl acetate. In our study, total esters concentrations were significantly higher in Babić and Frankovka sequentially fermented wines, while in Blatina and Trnjak wines, higher concentrations were in control variants. Babić and Trnjak sequentially produced wines that had higher concentrations of 2-phenylethyl acetate, even though in the work by Chen et al. [32], no differences were noted. Isoamyl acetate stood out with significantly lower concentrations in all sequentially fermented wines, which is in accordance with data published by [9]. Among ethyl esters, the most abundant was ethyl lactate, whose concentrations were significantly higher in all wines produced by sequential fermentation as a result of the greater lactic acid production involved with $L$. thermotolerans, which is also in accordance with previously published data $[32,33]$. From the data presented in Figure 1, it can be noted that in sequentially fermented wines, esters and higher alcohols were mainly presented in lower concentrations compared to control wines.

\subsubsection{Fatty Acids}

Initial must composition, as well as agricultural conditions and variety, can have a strong influence on fatty acids present in wine [34,35], which was confirmed by our data. In our work, total fatty acid concentrations were significantly higher in Babić and Frankovka sequentially fermented wines, mainly due to higher 2-methylpropionic acid concentrations, while in the other two, there was no difference. Fatty acid concentrations can also be significantly influenced by L. thermotolerans in combined fermentations, where lower production of hexanoic and octanoic acid was noted [27], which was also the case in Blatina, Frankovka, and Trnjak sequentially fermented wines. Babić wines produced with L. thermotolerans were the only ones with a higher concentration of isovaleric acid, which 
has been pointed out by previously published work [31] as one whose concentrations can also be influenced by the action of $L$. thermotolerans.

\subsubsection{Lactones}

Lactones mostly arise from the cyclization of the corresponding $\gamma$-hydroxycarboxylic acids, which are unstable molecules that can be formed by glutamic acid deamination and the decarboxylation process, pantolactone being an example [36-38]. Lactones may also come from grapes, as is the case in Riesling, where they contribute to the varietal aroma $[39,40]$. Our results show that $\gamma$-butyrolactone was the most abundant lactone in all analyzed wines, with significantly higher concentrations in Babić, Frankovka, and Trnjak sequentially produced wines in which also total lactone concentrations were significantly higher compared to control wines. In the work by Escribano et al. [31] L. thermotolerans was a higher $\gamma$-butyrolactone producer when compared with some non-Saccharomyces yeasts, but with no significant difference when compared to S. cerevisiae. Nakamura et al. [41] analyzed $\gamma$-nonalactone in 38 Californian and French wines, in which $\gamma$-nonalactone concentrations ranged from 0 to $16 \mu \mathrm{g} / \mathrm{L}$ in white samples and 12 to $43 \mu \mathrm{g} / \mathrm{L}$ in red ones. Concentrations of $\gamma$-nonalactone in our wines were in agreement with the results of Nakamura et al. [41] but significantly higher in Babić, Frankovka, and Trnjak control wines.

\subsubsection{Volatile Phenols}

Volatile phenols, such as guaiacol, eugenol, vanillin, 4-vinylguaiacol, and 4-vinylphenol, are relevant components of the hydrolysates obtained from fractions of precursors extracted from grapes or wines [42,43]. Among them, vinylguaiacol and vinylphenol can be formed by yeast phenolic acid decarboxylases or by enzymatic or acid hydrolyses of their glycosides, having a strong influence on wine quality if present at high levels [44]. Significantly higher concentrations of 4-vinylguaiacol and 4-vinylphenol were noted in Babić and Trnjak sequentially fermented wines but with no impact on wine sensory profile, as OAVs were $<1$. According to our data only eugenol concentrations were above the odor detection threshold, but with no significant differences between variants except in Babić wines, where control wines were more abundant. Even though the levels of vanillin derived from the grape cannot rival levels released by some types of oak wood, they can be released from a large number of grape precursors, for instance during enzymatic hydrolysates from grape berry skin or by oxidation of 4-vinylguaiacol [43]. Diversity in vanillin concentrations between $V$. vinifera aromatic varieties was also noted in work by D'Onofrio et al. [45]. In our work, higher concentrations of vanillin in Babić and Frankovka control wines may be connected with lower concentrations of 4-vinylguaiacol in the same ones. 


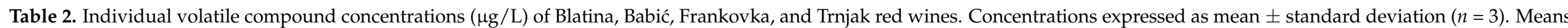
with different superscript letters, for each variety separately, in the same row differ significantly $(p \leq 0.05)$.

\begin{tabular}{|c|c|c|c|c|c|c|c|c|c|c|}
\hline & ODT ( $\mu \mathrm{g} / \mathrm{L})$ & $\begin{array}{c}\text { Odor } \\
\text { Descriptor }\end{array}$ & $\begin{array}{c}\text { Babić } \\
\text { Control }\end{array}$ & $\begin{array}{c}\text { Babić } \\
\text { Lachancea }\end{array}$ & $\begin{array}{l}\text { Blatina } \\
\text { Control }\end{array}$ & $\begin{array}{c}\text { Blatina } \\
\text { Lachancea }\end{array}$ & $\begin{array}{l}\text { Frankovka } \\
\text { Control }\end{array}$ & $\begin{array}{l}\text { Frankovka } \\
\text { Lachancea }\end{array}$ & $\begin{array}{l}\text { Trnjak } \\
\text { Control }\end{array}$ & $\begin{array}{c}\text { Trnjak } \\
\text { Lachancea }\end{array}$ \\
\hline \multicolumn{11}{|l|}{ Aldehydes } \\
\hline 2,4-Decadienal & $270[46]$ & Floral [47] & $0.17 \pm 0.01^{\mathrm{a}}$ & $0.04 \pm 0.02^{b}$ & $0.34 \pm 0.01^{\mathrm{a}}$ & $0.12 \pm 0.01^{b}$ & $0.31 \pm 0.04^{\mathrm{a}}$ & $0.18 \pm 0.01^{b}$ & $0.11 \pm 0.01^{\mathrm{a}}$ & $0.14 \pm 0.02^{\mathrm{a}}$ \\
\hline $\begin{array}{l}\text { 2,4-Heptadienal } \\
\text { (E,E) }\end{array}$ & & & $3.53 \pm 0.06^{\mathrm{a}}$ & $2.66 \pm 0.05^{b}$ & $4.47 \pm 0.03^{a}$ & $3.85 \pm 0.01^{b}$ & $2.68 \pm 0.44^{a}$ & $1.60 \pm 0.21^{\mathrm{a}}$ & $0.10 \pm 0.02^{\mathrm{a}}$ & $0.13 \pm 0.01^{\mathrm{a}}$ \\
\hline 2,4-Hexadienal & & & $1.88 \pm 0.11^{a}$ & $1.55 \pm 0.01^{a}$ & $1.46 \pm 0.05^{a}$ & $1.14 \pm 0.03^{b}$ & $1.31 \pm 0.14^{\mathrm{a}}$ & $1.36 \pm 0.11^{\mathrm{a}}$ & $1.31 \pm 0.19^{\mathrm{a}}$ & $1.54 \pm 0.04^{\mathrm{a}}$ \\
\hline 2,4-Nonadienal & $0.09[48]$ & $\begin{array}{c}\text { Cucumber } \\
{[26]}\end{array}$ & $0.09 \pm 0.01^{\mathrm{a}}$ & $0.02 \pm 0.01^{b}$ & $0.05 \pm 0.01^{\mathrm{a}}$ & $0.08 \pm 0.01^{\mathrm{a}}$ & $0.56 \pm 0.01^{b}$ & $0.77 \pm 0.03^{\mathrm{a}}$ & $0.37 \pm 0.31^{\mathrm{a}}$ & $0.44 \pm 0.39^{a}$ \\
\hline 2-Octenal & & & $1.29 \pm 0.49^{b}$ & $2.15 \pm 0.09^{a}$ & $4.21 \pm 1.01^{\mathrm{a}}$ & $3.72 \pm 0.66^{\mathrm{a}}$ & $6.35 \pm 0.74^{\mathrm{a}}$ & $6.64 \pm 0.78^{a}$ & $1.27 \pm 0.48^{b}$ & $4.11 \pm 0.47^{\mathrm{a}}$ \\
\hline $\begin{array}{l}\text { 5-Hydroxymethyl- } \\
\text { furfural }\end{array}$ & $100,000[49]$ & Almond [50] & $2.75 \pm 0.05^{\mathrm{a}}$ & $0.38 \pm 0.01^{b}$ & $0.61 \pm 0.06^{\mathrm{a}}$ & $0.18 \pm 0.02^{b}$ & $1.23 \pm 0.01^{\mathrm{a}}$ & $0.04 \pm 0.01^{b}$ & $0.15 \pm 0.19^{a}$ & $0.20 \pm 0.02^{\mathrm{a}}$ \\
\hline Benzaacetaldehyde & $4[51]$ & & $14.90 \pm 0.28^{\mathrm{a}}$ & $15.71 \pm 0.67^{\mathrm{a}}$ & $11.73 \pm 0.59^{a}$ & $9.84 \pm 0.03^{b}$ & $34.14 \pm 1.58^{\mathrm{a}}$ & $27.52 \pm 2.33^{a}$ & $34.60 \pm 1.24^{b}$ & $50.00 \pm 8.60^{\mathrm{a}}$ \\
\hline Benzaldehyde & $350[43]$ & $\begin{array}{c}\text { Bitter, almond } \\
\text { [52] }\end{array}$ & $7.54 \pm 0.06^{\mathrm{b}}$ & $7.81 \pm 0.06^{\mathrm{a}}$ & $3.50 \pm 0.28^{b}$ & $4.38 \pm 0.02^{\mathrm{a}}$ & $8.51 \pm 0.21^{\mathrm{a}}$ & $7.30 \pm 0.16^{\mathrm{b}}$ & $122.19 \pm 6.80^{b}$ & $155.29 \pm 10.11^{\mathrm{a}}$ \\
\hline Decanal & $0.1-2[53]$ & & $2.67 \pm 0.01^{\mathrm{a}}$ & $2.19 \pm 0.10^{b}$ & $1.74 \pm 0.06^{b}$ & $2.12 \pm 0.01^{\mathrm{a}}$ & $3.48 \pm 0.10^{b}$ & $3.89 \pm 0.01^{\mathrm{a}}$ & $1.60 \pm 0.16^{b}$ & $2.18 \pm 0.23^{\mathrm{a}}$ \\
\hline Furfural & $770[54]$ & $\begin{array}{c}\text { Almond, yeast } \\
{[55]}\end{array}$ & $5.31 \pm 0.69^{\mathrm{a}}$ & $2.07 \pm 0.01^{b}$ & $1.93 \pm 0.09^{\mathrm{a}}$ & $1.74 \pm 0.02^{\mathrm{a}}$ & $0.65 \pm 0.01^{\mathrm{a}}$ & $0.13 \pm 0.01^{b}$ & $3.23 \pm 0.23^{b}$ & $6.79 \pm 0.48^{\mathrm{a}}$ \\
\hline$\Sigma$ & & & $40.11^{\mathrm{a}}$ & $34.56^{\mathrm{b}}$ & $30.01^{\mathrm{a}}$ & $27.17^{b}$ & $59.20^{\mathrm{a}}$ & $49.42^{b}$ & $164.86^{\mathrm{b}}$ & $220.74^{\mathrm{a}}$ \\
\hline \multicolumn{11}{|l|}{ Higher alcohols } \\
\hline 1-Butanol & $150,000[56]$ & Medicinal [43] & $185.27 \pm 1.41^{\mathrm{a}}$ & $153.08 \pm 3.13^{b}$ & $168.70 \pm 1.63^{\mathrm{a}}$ & $155.30 \pm 1.54^{\mathrm{b}}$ & $156.25 \pm 2.85^{b}$ & $243.53 \pm 1.00^{\mathrm{a}}$ & $108.29 \pm 9.09^{b}$ & $192.29 \pm 13.62^{a}$ \\
\hline 1-Decanol & $5000[57]$ & $\begin{array}{l}\text { Pear, waxy, } \\
\text { violet [57] }\end{array}$ & $5.23 \pm 0.01^{\mathrm{a}}$ & $4.80 \pm 0.03^{b}$ & $1.15 \mathrm{~b} \pm 0.01^{\mathrm{b}}$ & $6.05 \pm 0.01^{\mathrm{a}}$ & $2.20 \pm 0.01^{\mathrm{a}}$ & $0.64 \pm 0.04^{\mathrm{b}}$ & $2.73 \pm 0.33^{a}$ & $1.89 \pm 0.35^{b}$ \\
\hline 1-Heptanol & $425[51]$ & Oily [47] & $29.01 \pm 0.92^{\mathrm{a}}$ & $32.15 \pm 1.58^{a}$ & $19.22 \pm 0.62^{\mathrm{a}}$ & $17.68 \pm 0.71^{\mathrm{a}}$ & $19.34 \pm 0.03^{a}$ & $7.78 \pm 0.16^{b}$ & $32.72 \pm 0.96^{\mathrm{a}}$ & $31.72 \pm 4.75^{\mathrm{a}}$ \\
\hline 1-Hexanol & $2500[55]$ & $\begin{array}{c}\text { Grass just cut } \\
\text { [43] }\end{array}$ & $1464.07 \pm 1.56^{b}$ & $1484.66 \pm 1.46^{\mathrm{a}}$ & $1872.75 \pm 4.77^{\mathrm{a}}$ & $1764.33 \pm 1.21^{b}$ & $868.37 \pm 1.45^{\mathrm{a}}$ & $729.93 \pm 0.52^{b}$ & $\underset{\mathrm{a}}{2581.10 \pm 41.61}$ & $\begin{array}{c}2642.37 \pm \\
a\end{array}$ \\
\hline 1-Nonanol & & & $4.18 \pm 0.10^{\mathrm{a}}$ & $3.78 \pm 0.01^{b}$ & $5.64 \pm 0.08^{\mathrm{a}}$ & $4.29 \pm 0.01^{\mathrm{b}}$ & $4.98 \pm 0.13^{\mathrm{a}}$ & $1.50 \pm 0.06^{\mathrm{b}}$ & $5.40 \pm 0.27^{\mathrm{a}}$ & $4.58 \pm 1.20^{\mathrm{a}}$ \\
\hline 1-Octadecanol & & & $22.97 \pm 0.69^{\mathrm{a}}$ & $0.22 \pm 0.01^{\mathrm{b}}$ & $0.34 \pm 0.01^{\mathrm{a}}$ & $0.33 \pm 0.04^{\mathrm{a}}$ & $25.16 \pm 0.56^{\mathrm{a}}$ & $0.07 \pm 0.03^{b}$ & $1.74 \pm 0.16^{\mathrm{a}}$ & $0.29 \pm 2.59^{a}$ \\
\hline 1-Octanol & $110-130$ [53] & Chemical [43] & $34.66 \pm 0.66^{b}$ & $39.62 \pm 0.70^{a}$ & $9.45 \pm 0.04^{b}$ & $11.79 \pm 0.49^{\mathrm{a}}$ & $15.14 \pm 1.10^{\mathrm{a}}$ & $11.12 \pm 0.30^{b}$ & $22.99 \pm 1.85^{\mathrm{a}}$ & $10.46 \pm 2.69^{b}$ \\
\hline 1-Pentanol & $64,000[37]$ & $\begin{array}{l}\text { Bitter, almond, } \\
\text { balsamic [37] }\end{array}$ & $0.48 \pm 0.01^{b}$ & $34.97 \pm 0.97^{\mathrm{a}}$ & $32.37 \pm 1.06^{\mathrm{a}}$ & $30.04 \pm 0.73^{a}$ & $30.42 \pm 1.20^{\mathrm{a}}$ & $26.80 \pm 0.13^{a}$ & $0.10 \pm 0.06^{\mathrm{a}}$ & $0.13 \pm 0.02^{\mathrm{a}}$ \\
\hline
\end{tabular}


Table 2. Cont.

\begin{tabular}{|c|c|c|c|c|c|c|c|c|c|c|}
\hline & ODT ( $\mu \mathrm{g} / \mathrm{L})$ & $\begin{array}{c}\text { Odor } \\
\text { Descriptor }\end{array}$ & $\begin{array}{l}\text { Babić } \\
\text { Control }\end{array}$ & $\begin{array}{c}\text { Babić } \\
\text { Lachancea }\end{array}$ & $\begin{array}{l}\text { Blatina } \\
\text { Control }\end{array}$ & $\begin{array}{c}\text { Blatina } \\
\text { Lachancea }\end{array}$ & $\begin{array}{c}\text { Frankovka } \\
\text { Control }\end{array}$ & $\begin{array}{l}\text { Frankovka } \\
\text { Lachancea }\end{array}$ & $\begin{array}{l}\text { Trnjak } \\
\text { Control }\end{array}$ & $\begin{array}{c}\text { Trnjak } \\
\text { Lachancea }\end{array}$ \\
\hline 2-Pentadecanol & & & $0.95 \pm 0.01^{a}$ & $0.24 \pm 0.02^{b}$ & $0.34 \pm 0.04^{\mathrm{a}}$ & $0.17 \pm 0.03^{b}$ & $1.01 \pm 0.02^{\mathrm{a}}$ & $0.33 \pm 0.01^{b}$ & $3.07 \pm 0.32^{\mathrm{a}}$ & $2.28 \pm 0.51^{\mathrm{a}}$ \\
\hline 2-Pentene-1-ol & & & $0.14 \pm 0.04^{b}$ & $0.38 \pm 0.01^{\mathrm{a}}$ & $3.07 \pm 0.03^{a}$ & $2.65 \pm 0.01^{b}$ & $0.24 \pm 0.07^{\mathrm{a}}$ & $0.15 \pm 0.07^{\mathrm{a}}$ & $2.77 \pm 0.20^{b}$ & $3.85 \pm 0.30^{\mathrm{a}}$ \\
\hline $\begin{array}{l}\text { 2-Methyl-1- } \\
\text { butanol }\end{array}$ & $30,000[58]$ & $\begin{array}{l}\text { Whiskey, } \\
\text { burnt, nail } \\
\text { polish [59] }\end{array}$ & $\begin{array}{c}13,752.80 \pm \\
69.76^{\mathrm{b}}\end{array}$ & $\underset{\mathrm{a}}{14,600.50} \pm 1.87$ & $\underset{\mathrm{b}}{12,760.75} \pm 3.58$ & $\underset{\mathrm{a}}{13,794.74} \pm 3.50$ & $\begin{array}{c}19,820.03 \pm \\
396.27^{a}\end{array}$ & $\begin{array}{c}16,713.06 \pm \\
437.03^{\mathrm{b}}\end{array}$ & $\begin{array}{c}25,883.52 \pm \\
353.92^{\mathrm{a}}\end{array}$ & $\begin{array}{c}26,051.04 \pm \\
77.75^{\text {a }}\end{array}$ \\
\hline 2-Ethyl-1-hexanol & & & $3.93 \pm 0.08^{b}$ & $5.50 \pm 0.07^{\mathrm{a}}$ & $0.11 \pm 0.01^{\mathrm{a}}$ & $0.10 \pm 0.01^{\mathrm{a}}$ & $1.11 \pm 0.01^{\mathrm{a}}$ & $0.77 \pm 0.01^{b}$ & $2.14 \pm 0.17^{\mathrm{a}}$ & $2.68 \pm 0.58^{a}$ \\
\hline $\begin{array}{l}\text { trans-2-Hexene-1- } \\
\text { ol }\end{array}$ & $100[60]$ & $\begin{array}{l}\text { Herbaceous, } \\
\text { green [47] }\end{array}$ & $11.73 \pm 0.78^{a}$ & $11.75 \pm 0.73^{a}$ & $5.08 \pm 0.02^{\mathrm{a}}$ & $4.89 \pm 0.13^{\mathrm{a}}$ & $5.63 \pm 0.42^{b}$ & $7.90 \pm 0.01^{\mathrm{a}}$ & $7.87 \pm 0.19^{\mathrm{a}}$ & $7.48 \pm 0.79^{a}$ \\
\hline cis-3-Hexene-1-ol & $400[43]$ & $\begin{array}{c}\text { Grass, green } \\
{[43]}\end{array}$ & $16.57 \pm 0.07^{b}$ & $21.59 \pm 0.76^{\mathrm{a}}$ & $76.66 \pm 0.69^{a}$ & $72.26 \pm 0.47^{b}$ & $18.95 \pm 0.69^{a}$ & $19.95 \pm 0.37^{\mathrm{a}}$ & $141.29 \pm 5.90^{b}$ & $190.06 \pm 18.90^{\mathrm{a}}$ \\
\hline $\begin{array}{l}\text { trans-3-Hexene-1- } \\
\text { ol }\end{array}$ & $1000[43]$ & $\begin{array}{l}\text { Grass, } \\
\text { resinous, } \\
\text { cream [43] }\end{array}$ & $47.73 \pm 0.74^{\mathrm{a}}$ & $32.66 \pm 19.75^{\mathrm{a}}$ & $30.22 \pm 1.05^{\mathrm{a}}$ & $29.88 \pm 0.61^{\mathrm{a}}$ & $25.74 \pm 0.88^{a}$ & $28.33 \pm 0.78^{a}$ & $31.50 \pm 0.78^{a}$ & $31.29 \pm 3.71^{\mathrm{a}}$ \\
\hline $\begin{array}{l}\text { Phenylethyl } \\
\text { alcohol }\end{array}$ & $14,000[61]$ & $\begin{array}{l}\text { Floral, rose, } \\
\text { honey [57] }\end{array}$ & $5176.93 \pm 1.85^{b}$ & $6465.90 \pm 4.74^{\mathrm{a}}$ & $6974.79 \pm 0.50^{\mathrm{a}}$ & $6695.82 \pm 0.47^{b}$ & $9971.16 \pm 0.51^{\mathrm{a}}$ & $6307.75 \pm 0.52^{\mathrm{b}}$ & $\begin{array}{c}7311.89 \pm 188.33 \\
a\end{array}$ & $\begin{array}{c}7536.44 \pm 708.53 \\
\text { a }\end{array}$ \\
\hline Isoamyl alcohol & $30,000[58]$ & $\begin{array}{l}\text { Alcohol, nail } \\
\text { polish [57] }\end{array}$ & $\underset{\mathrm{a}}{12,130.23} \pm 7.52$ & $5566.17 \pm 0.70^{b}$ & $\underset{\mathrm{a}}{10,960.85} \pm 6.62$ & $\begin{array}{c}10,430.94 \\
\mathrm{~b}\end{array}$ & $\begin{array}{c}17,083.44 \pm \\
23.84^{\text {a }} \\
\end{array}$ & $\begin{array}{c}14,469.53 \pm \\
23.50^{\mathrm{b}} \\
\end{array}$ & $\begin{array}{c}9621.08 \pm \\
4725.72^{\mathrm{a}} \\
\end{array}$ & $\begin{array}{l}9022.92 \pm \\
2075.75^{\mathrm{b}}\end{array}$ \\
\hline Isobutanol & $40,000[37]$ & $\begin{array}{l}\text { Alcohol, nail } \\
\text { polish [57] }\end{array}$ & $4548.47 \pm 1.29^{b}$ & $6089.32 \pm 6.86^{\mathrm{a}}$ & $3414.33 \pm 5.55^{\mathrm{a}}$ & $3055.67 \pm 3.63^{b}$ & $6135.18 \pm 0.98^{b}$ & $6702.63 \pm 3.66^{\mathrm{a}}$ & $\begin{array}{c}3370.62 \pm 160.10 \\
\mathrm{~b}\end{array}$ & $\underset{\mathrm{a}}{5077.13 \pm 394.26}$ \\
\hline$\Sigma$ & & & $37,436.96^{a}$ & $34,548.24^{b}$ & $36,337.69^{a}$ & $36,078.53^{b}$ & $54,184.46^{a}$ & $45,271.83^{b}$ & $49,131.05^{a}$ & $50,809.20^{a}$ \\
\hline \multicolumn{11}{|l|}{ Volatile phenols } \\
\hline 4-Vinylguaiacol & $40[62]$ & $\begin{array}{c}\text { Clove, curry } \\
\text { [43] }\end{array}$ & $0.93 \pm 0.08^{b}$ & $1.57 \pm 0.02^{\mathrm{a}}$ & $19.62 \pm 0.71^{\mathrm{a}}$ & $15.01 \pm 0.06^{\mathrm{b}}$ & $0.90 \pm 0.01^{b}$ & $3.19 \pm 0.08^{\mathrm{a}}$ & $10.51 \pm 0.56^{\mathrm{b}}$ & $26.23 \pm 4.79^{a}$ \\
\hline 4-Vinylphenol & 180 [61] & $\begin{array}{c}\text { Phenolic, } \\
\text { medicinal [43] }\end{array}$ & $0.30 \pm 0.02^{b}$ & $1.04 \pm 0.01^{\mathrm{a}}$ & $28.49 \pm 1.48^{a}$ & $26.75 \pm 0.99^{a}$ & $3.54 \pm 0.01^{\mathrm{a}}$ & $1.07 \pm 0.03^{b}$ & $6.96 \pm 1.00^{\mathrm{b}}$ & $50.32 \pm 4.95^{\mathrm{a}}$ \\
\hline Eugenol & $6[54]$ & $\begin{array}{l}\text { Cinnamon, } \\
\text { clove [43] }\end{array}$ & $2.38 \pm 0.04^{\mathrm{a}}$ & $1.87 \pm 0.03^{\mathrm{b}}$ & $9.39 \pm 0.22^{\mathrm{a}}$ & $9.12 \pm 0.09^{\mathrm{a}}$ & $4.08 \pm 0.04^{\mathrm{a}}$ & $4.28 \pm 0.23^{a}$ & $33.98 \pm 0.87^{a}$ & $30.16 \pm 4.02^{\mathrm{a}}$ \\
\hline Guaiacol & $9.5[55]$ & $\begin{array}{c}\text { Smoky, } \\
\text { hospital [55] }\end{array}$ & $5.70 \pm 0.29^{a}$ & $2.25 \pm 0.05^{b}$ & $1.48 \pm 0.01^{\mathrm{a}}$ & $1.07 \pm 0.04^{b}$ & $1.95 \pm 0.06^{\mathrm{a}}$ & $1.87 \pm 0.04^{\mathrm{a}}$ & $3.40 \pm 0.09^{a}$ & $2.86 \pm 0.74^{\mathrm{a}}$ \\
\hline $\begin{array}{l}\text { Homovanillyl } \\
\text { alcohol }\end{array}$ & & & $85.19 \pm 0.57^{b}$ & $90.39 \pm 1.12^{\mathrm{a}}$ & $17.21 \pm 0.08^{a}$ & $16.78 \pm 0.95^{\mathrm{a}}$ & $124.39 \pm 1.66^{\mathrm{a}}$ & $118.71 \pm 0.74^{\mathrm{b}}$ & $41.77 \pm 2.30^{\mathrm{b}}$ & $72.86 \pm 10.72^{\mathrm{a}}$ \\
\hline
\end{tabular}


Table 2. Cont.

\begin{tabular}{|c|c|c|c|c|c|c|c|c|c|c|}
\hline & ODT $(\mu \mathrm{g} / \mathrm{L})$ & $\begin{array}{c}\text { Odor } \\
\text { Descriptor }\end{array}$ & $\begin{array}{c}\text { Babić } \\
\text { Control }\end{array}$ & $\begin{array}{c}\text { Babić } \\
\text { Lachancea }\end{array}$ & $\begin{array}{l}\text { Blatina } \\
\text { Control }\end{array}$ & $\begin{array}{c}\text { Blatina } \\
\text { Lachancea }\end{array}$ & $\begin{array}{l}\text { Frankovka } \\
\text { Control }\end{array}$ & $\begin{array}{c}\text { Frankovka } \\
\text { Lachancea }\end{array}$ & $\begin{array}{c}\text { Trnjak } \\
\text { Control }\end{array}$ & $\begin{array}{c}\text { Trnjak } \\
\text { Lachancea }\end{array}$ \\
\hline Vanillin & $200[58]$ & Vanilla [43] & $17.72 \pm 1.40^{\mathrm{a}}$ & $5.57 \pm 0.22^{b}$ & $8.15 \pm 0.01^{a}$ & $7.18 \pm 0.02^{b}$ & $7.76 \pm 0.31^{\mathrm{a}}$ & $4.19 \pm 0.11^{b}$ & $16.46 \pm 2.05^{a}$ & $17.44 \pm 2.00^{\mathrm{a}}$ \\
\hline$\Sigma$ & & & $112.22^{\mathrm{a}}$ & $102.69^{a}$ & $84.32^{\mathrm{a}}$ & $75.89^{a}$ & $142.60^{\mathrm{a}}$ & $133.30^{\mathrm{a}}$ & $113.11^{b}$ & $199.87^{a}$ \\
\hline \multicolumn{11}{|l|}{ Terpenes } \\
\hline 1,8-Terpin & & & $1.77 \pm 0.04^{\mathrm{a}}$ & $1.01 \pm 0.02^{b}$ & $0.36 \pm 0.01^{b}$ & $1.43 \pm 0.06^{\mathrm{a}}$ & $0.95 \pm 0.06^{\mathrm{b}}$ & $1.26 \pm 0.01^{\mathrm{a}}$ & $0.99 \pm 0.22^{b}$ & $2.08 \pm 0.88^{a}$ \\
\hline $\begin{array}{c}\text { 6,7-Dihydro-7- } \\
\text { hydroxylinalool }\end{array}$ & & & $33.04 \pm 0.93^{a}$ & $9.23 \pm 0.08^{b}$ & $6.56 \pm 0.15^{\mathrm{a}}$ & $5.46 \pm 0.13^{b}$ & $12.60 \pm 0.59^{a}$ & $12.05 \pm 1.07^{\mathrm{a}}$ & $5.50 \pm 0.96^{\mathrm{a}}$ & $6.18 \pm 2.41^{\mathrm{a}}$ \\
\hline$\alpha$-Pinene & & & $0.12 \pm 0.01^{\mathrm{a}}$ & $0.10 \pm 0.01^{\mathrm{a}}$ & $0.04 \pm 0.01^{b}$ & $0.54 \pm 0.02^{\mathrm{a}}$ & $0.22 \pm 0.01^{\mathrm{a}}$ & $0.15 \pm 0.06^{\mathrm{a}}$ & $1.10 \pm 0.26^{\mathrm{a}}$ & $1.99 \pm 0.90^{\mathrm{a}}$ \\
\hline$\alpha$-Terpineol & 330 [63] & $\begin{array}{l}\text { Lilac, floral, } \\
\text { sweet [43] }\end{array}$ & $1.95 \pm 0.06^{\mathrm{a}}$ & $1.18 \pm 0.02^{b}$ & $2.37 \pm 0.04^{\mathrm{a}}$ & $2.75 \pm 0.21^{\mathrm{a}}$ & $9.90 \pm 0.21^{\mathrm{a}}$ & $8.42 \pm 0.42^{b}$ & $6.87 \pm 0.19^{a}$ & $7.28 \pm 1.07^{\mathrm{a}}$ \\
\hline $\begin{array}{l}\text { 2,6-Dimethyl-3,7- } \\
\text { octadiene-2,6-diol }\end{array}$ & & & $0.87 \pm 0.03^{a}$ & $0.08 \pm 0.01^{b}$ & $0.17 \pm 0.04^{a}$ & $0.17 \pm 0.03^{\mathrm{a}}$ & $55.68 \pm 0.63^{a}$ & $52.18 \pm 1.41^{\mathrm{a}}$ & $0.87 \pm 0.23^{a}$ & $1.10 \pm 0.41^{\mathrm{a}}$ \\
\hline $\begin{array}{l}\text { 2,6-Dimethyl-7- } \\
\text { octene-2,6-diol }\end{array}$ & & & $32.62 \pm 0.70^{a}$ & $7.98 \pm 0.01^{b}$ & $5.93 \pm 0.01^{\mathrm{a}}$ & $1.74 \pm 0.02^{b}$ & $1.89 \pm 0.09^{b}$ & $2.48 \pm 0.01^{\mathrm{a}}$ & $4.98 \pm 0.48^{a}$ & $7.37 \pm 2.82^{a}$ \\
\hline$\beta$-Ocimene & & & $0.69 \pm 0.06^{\mathrm{a}}$ & $0.38 \pm 0.02^{b}$ & $0.56 \pm 0.04^{\mathrm{a}}$ & $0.82 \pm 0.09^{a}$ & $0.43 \pm 0.04^{\mathrm{a}}$ & $0.28 \pm 0.02^{b}$ & $0.38 \pm 0.17^{a}$ & $0.27 \pm 0.05^{a}$ \\
\hline $\begin{array}{l}\text { cis,trans- } \alpha- \\
\text { Farnesene }\end{array}$ & & & $1.74 \pm 0.02^{\mathrm{a}}$ & $1.75 \pm 0.04^{\mathrm{a}}$ & $1.18 \pm 0.02^{\mathrm{a}}$ & $1.13 \pm 0.04^{\mathrm{a}}$ & $1.95 \pm 0.06^{\mathrm{a}}$ & $1.65 \pm 0.01^{b}$ & $1.82 \pm 0.27^{b}$ & $2.44 \pm 0.16^{a}$ \\
\hline trans- $\beta$-Farnesene & $87[64]$ & & $0.83 \pm 0.08^{\mathrm{a}}$ & $0.73 \pm 0.02^{\mathrm{a}}$ & $0.95 \pm 0.04^{a}$ & $0.72 \pm 0.01^{b}$ & $0.85 \pm 0.06^{\mathrm{a}}$ & $0.66 \pm 0.05^{\mathrm{a}}$ & $0.59 \pm 0.10^{\mathrm{a}}$ & $0.68 \pm 0.05^{a}$ \\
\hline cis- $\beta$-Farnesene & & & $2.27 \pm 0.03^{\mathrm{a}}$ & $1.18 \pm 0.01^{b}$ & $0.87 \pm 0.02^{\mathrm{a}}$ & $0.65 \pm 0.01^{b}$ & $1.18 \pm 0.01^{\mathrm{a}}$ & $0.90 \pm 0.08^{b}$ & $0.90 \pm 0.08^{b}$ & $1.43 \pm 0.13^{\mathrm{a}}$ \\
\hline $\begin{array}{l}\text { cis-Linalool oxide, } \\
\text { furan }\end{array}$ & $6000[55]$ & Flower [55] & $0.57 \pm 0.03^{a}$ & $0.65 \pm 0.04^{a}$ & $0.16 \pm 0.01^{\mathrm{a}}$ & $0.01 \pm 0.00^{\mathrm{b}}$ & $0.91 \pm 0.02^{b}$ & $1.04 \pm 0.01^{\mathrm{a}}$ & $0.44 \pm 0.22^{\mathrm{a}}$ & $0.81 \pm 0.17^{a}$ \\
\hline Citronellol & 40 [63] & Rose [65] & $39.05 \pm 0.28^{a}$ & $35.06 \pm 0.89^{b}$ & $23.84 \pm 0.45^{\mathrm{a}}$ & $22.99 \pm 1.00^{\mathrm{a}}$ & $59.13 \pm 0.33^{a}$ & $42.88 \pm 0.54^{b}$ & $45.75 \pm 2.55^{\mathrm{a}}$ & $43.35 \pm 7.64^{\mathrm{a}}$ \\
\hline Farnesol & $20[66]$ & $\begin{array}{c}\text { Floral, clove } \\
\quad[47]\end{array}$ & $2.39 \pm 0.14^{b}$ & $14.13 \pm 0.21^{\mathrm{a}}$ & $8.40 \pm 0.23^{a}$ & $7.33 \pm 0.08^{b}$ & $43.92 \pm 0.29^{a}$ & $39.77 \pm 0.65^{b}$ & $9.44 \pm 0.35^{\mathrm{a}}$ & $9.12 \pm 2.82^{a}$ \\
\hline Geraniol & $20[61]$ & Citrus [43] & $6.65 \pm 2.11^{b}$ & $12.05 \pm 1.24^{\mathrm{a}}$ & $0.96 \pm 0.04^{b}$ & $4.42 \pm 0.10^{\mathrm{a}}$ & $0.56 \pm 0.04^{b}$ & $14.10 \pm 0.18^{a}$ & $12.03 \pm 0.42^{b}$ & $17.39 \pm 1.73^{\mathrm{a}}$ \\
\hline Geranyl acetate & $9[67]$ & Flowery [67] & $4.41 \pm 0.05^{b}$ & $8.83 \pm 0.03^{a}$ & $3.54 \pm 0.01^{b}$ & $3.67 \pm 0.04^{\mathrm{a}}$ & $5.47 \pm 0.01^{b}$ & $7.04 \pm 0.01^{\mathrm{a}}$ & $3.11 \pm 0.43^{b}$ & $6.82 \pm 1.27^{a}$ \\
\hline Hotrienol & $110[52]$ & $\begin{array}{l}\text { Fresh, floral, } \\
\text { sweet [52] }\end{array}$ & $12.31 \pm 1.34^{\mathrm{a}}$ & $8.84 \pm 0.01^{\mathrm{a}}$ & $1.74 \pm 0.01^{b}$ & $2.62 \pm 0.04^{a}$ & $155.03 \pm 0.13^{a}$ & $100.95 \pm 0.28^{b}$ & $2.83 \pm 0.33^{a}$ & $0.82 \pm 0.82^{b}$ \\
\hline Linalool & $25[61]$ & $\begin{array}{l}\text { Citrus, floral, } \\
\text { sweet [43] }\end{array}$ & $22.31 \pm 1.25^{b}$ & $30.66 \pm 0.85^{a}$ & $22.93 \pm 0.32^{a}$ & $21.56 \pm 0.69^{a}$ & $76.33 \pm 0.08^{a}$ & $40.06 \pm 0.09^{b}$ & $18.82 \pm 0.36^{a}$ & $18.57 \pm 3.05^{\mathrm{a}}$ \\
\hline
\end{tabular}


Table 2. Cont.

\begin{tabular}{|c|c|c|c|c|c|c|c|c|c|c|}
\hline & ODT ( $\mu \mathrm{g} / \mathrm{L})$ & $\begin{array}{c}\text { Odor } \\
\text { Descriptor }\end{array}$ & $\begin{array}{l}\text { Babić } \\
\text { Control }\end{array}$ & $\begin{array}{c}\text { Babić } \\
\text { Lachancea }\end{array}$ & $\begin{array}{l}\text { Blatina } \\
\text { Control }\end{array}$ & $\begin{array}{c}\text { Blatina } \\
\text { Lachancea }\end{array}$ & $\begin{array}{c}\text { Frankovka } \\
\text { Control }\end{array}$ & $\begin{array}{l}\text { Frankovka } \\
\text { Lachancea }\end{array}$ & $\begin{array}{l}\text { Trnjak } \\
\text { Control }\end{array}$ & $\begin{array}{c}\text { Trnjak } \\
\text { Lachancea }\end{array}$ \\
\hline Neral & & & $1.16 \pm 0.01^{b}$ & $4.09 \pm 0.03^{a}$ & $1.04 \pm 0.02^{b}$ & $1.15 \pm 0.01^{\mathrm{a}}$ & $4.98 \pm 0.07^{\mathrm{a}}$ & $1.64 \pm 0.02^{b}$ & $2.34 \pm 0.15^{a}$ & $0.85 \pm 0.25^{b}$ \\
\hline Nerolidol & $250[51]$ & $\begin{array}{c}\text { Rose, apple, } \\
\text { green, waxy } \\
{[47]}\end{array}$ & $1.16 \pm 0.04^{\mathrm{a}}$ & $0.95 \pm 0.06^{\mathrm{a}}$ & $0.64 \pm 0.01^{b}$ & $1.25 \pm 0.06^{\mathrm{a}}$ & $0.85 \pm 0.04^{a}$ & $0.76 \pm 0.04^{\mathrm{a}}$ & $1.04 \pm 0.20^{\mathrm{a}}$ & $0.85 \pm 0.23^{a}$ \\
\hline Neric acid & & & $3.26 \pm 0.04^{b}$ & $3.56 \pm 0.05^{\mathrm{a}}$ & $3.09 \pm 0.01^{\mathrm{a}}$ & $2.74 \pm 0.06^{b}$ & $3.89 \pm 0.10^{a}$ & $3.85 \pm 0.06^{\mathrm{a}}$ & $3.07 \pm 0.47^{\mathrm{a}}$ & $3.01 \pm 0.24^{\mathrm{a}}$ \\
\hline Nerol & $300[63]$ & $\begin{array}{l}\text { Rose, fruity, } \\
\text { floral [43] }\end{array}$ & $3.45 \pm 0.01^{\mathrm{a}}$ & $3.51 \pm 0.52^{\mathrm{a}}$ & $1.95 \pm 0.01^{\mathrm{a}}$ & $1.59 \pm 0.01^{b}$ & $1.15 \pm 0.01^{b}$ & $3.68 \pm 0.04^{a}$ & $5.01 \pm 0.18^{b}$ & $6.07 \pm 0.58^{a}$ \\
\hline Menthol & & & $0.63 \pm 0.05^{b}$ & $1.14 \pm 0.02^{\mathrm{a}}$ & $0.43 \pm 0.06^{b}$ & $0.91 \pm 0.06^{\mathrm{a}}$ & $0.67 \pm 0.03^{b}$ & $0.85 \pm 0.01^{\mathrm{a}}$ & $1.07 \pm 0.34^{\mathrm{a}}$ & $0.92 \pm 0.26^{\mathrm{a}}$ \\
\hline Ocimenol & & & $0.90 \pm 0.01^{\mathrm{a}}$ & $0.64 \pm 0.07^{b}$ & $2.66 \pm 0.05^{\mathrm{a}}$ & $0.02 \pm 0.01^{b}$ & $1.37 \pm 0.19^{\mathrm{a}}$ & $0.06 \pm 0.04^{b}$ & $2.56 \pm 0.64^{b}$ & $4.46 \pm 0.98^{a}$ \\
\hline Terpendiol I & & & $3.21 \pm 0.12^{\mathrm{a}}$ & $1.77 \pm 0.03^{b}$ & $6.03 \pm 0.03^{a}$ & $5.38 \pm 0.02^{b}$ & $0.21 \pm 0.02^{\mathrm{a}}$ & $0.30 \pm 0.02^{a}$ & $2.06 \pm 0.12^{\mathrm{a}}$ & $0.18 \pm 3.30^{b}$ \\
\hline Terpendiol II & & & $0.65 \pm 0.01^{b}$ & $1.10 \pm 0.01^{\mathrm{a}}$ & $0.40 \pm 0.08^{a}$ & $0.45 \pm 0.06^{\mathrm{a}}$ & $74.29 \pm 0.95^{b}$ & $94.80 \pm 0.59^{a}$ & $1.99 \pm 1.04^{\mathrm{a}}$ & $0.80 \pm 0.41^{\mathrm{a}}$ \\
\hline Terpinene-4-ol & & & $4.38 \pm 0.13^{a}$ & $2.16 \pm 0.04^{b}$ & $1.97 \pm 0.03^{b}$ & $2.57 \pm 0.04^{\mathrm{a}}$ & $0.97 \pm 0.03^{\mathrm{a}}$ & $0.54 \pm 0.02^{b}$ & $4.84 \pm 4.15^{\mathrm{b}}$ & $6.52 \pm 0.68^{a}$ \\
\hline Tetrahydrolinalool & & & $21.68 \pm 0.78^{b}$ & $89.23 \pm 0.65^{a}$ & $33.82 \pm 0.47^{\mathrm{a}}$ & $31.93 \pm 0.69^{\mathrm{a}}$ & $28.00 \pm 0.93^{\mathrm{a}}$ & $19.43 \pm 0.43^{b}$ & $11.60 \pm 0.28^{a}$ & $10.50 \pm 1.68^{a}$ \\
\hline Linalyl formate & & & $2.33 \pm 0.03^{a}$ & $0.28 \pm 0.01^{b}$ & $0.01 \pm 0.01^{b}$ & $2.44 \pm 0.04^{\mathrm{a}}$ & $0.33 \pm 0.03^{b}$ & $0.74 \pm 0.01^{\mathrm{a}}$ & $0.25 \pm 0.14^{\mathrm{a}}$ & $0.27 \pm 0.23^{a}$ \\
\hline \multicolumn{11}{|l|}{$\begin{array}{c}\mathrm{C} 13 \\
\text { Norisoprenoids }\end{array}$} \\
\hline$\alpha$-Ionol & & & $0.32 \pm 0.01^{\mathrm{a}}$ & $0.26 \pm 0.05^{\mathrm{a}}$ & $0.29 \pm 0.06^{\mathrm{a}}$ & $0.24 \pm 0.02^{\mathrm{a}}$ & $0.30 \pm 0.01^{\mathrm{a}}$ & $0.21 \pm 0.04^{\mathrm{a}}$ & $0.41 \pm 0.03^{a}$ & $0.44 \pm 0.16^{\mathrm{a}}$ \\
\hline$\beta$-Ionon & $3.4[68]$ & Flora 1 [68] & $0.13 \pm 0.03^{a}$ & $0.10 \pm 0.01^{\mathrm{a}}$ & $0.17 \pm 0.04^{\mathrm{a}}$ & $0.17 \pm 0.03^{a}$ & $0.10 \pm 0.01^{\mathrm{a}}$ & $0.10 \pm 0.02^{\mathrm{a}}$ & $0.53 \pm 0.02^{a}$ & $0.60 \pm 0.07^{\mathrm{a}}$ \\
\hline $\begin{array}{l}\beta \text {-Ionone-5,6- } \\
\text { epoxide }\end{array}$ & & & $0.28 \pm 0.02^{a}$ & $0.16 \pm 0.01^{b}$ & $0.06 \pm 0.02^{a}$ & $0.04 \pm 0.01^{\mathrm{a}}$ & $0.19 \pm 0.01^{\mathrm{a}}$ & $0.16 \pm 0.01^{\mathrm{a}}$ & $0.28 \pm 0.20^{a}$ & $0.17 \pm 0.11^{\mathrm{a}}$ \\
\hline$\beta$-Damascenone & $0.05[58]$ & $\begin{array}{c}\text { Sweet, fruity, } \\
\text { floral, honey } \\
\text { [61] }\end{array}$ & $9.24 \pm 0.42^{\mathrm{a}}$ & $8.51 \pm 0.02^{a}$ & $3.76 \pm 0.01^{\mathrm{a}}$ & $2.45 \pm 0.05^{b}$ & $5.54 \pm 0.02^{\mathrm{a}}$ & $5.61 \pm 0.25^{\mathrm{a}}$ & $4.79 \pm 0.25^{\mathrm{a}}$ & $6.52 \pm 1.17^{a}$ \\
\hline TDN & $2[69]$ & $\begin{array}{c}\text { Petrol, } \\
\text { kerosene [55] }\end{array}$ & $1.10 \pm 0.01^{\mathrm{a}}$ & $1.24 \pm 0.07^{\mathrm{a}}$ & $0.40 \pm 0.01^{\mathrm{a}}$ & $0.32 \pm 0.01^{b}$ & $0.71 \pm 0.02^{\mathrm{a}}$ & $0.62 \pm 0.06^{\mathrm{a}}$ & $0.54 \pm 0.02^{\mathrm{a}}$ & $0.87 \pm 0.46^{\mathrm{a}}$ \\
\hline$\Sigma$ & & & $11.06^{\mathrm{a}}$ & $10.26^{\mathrm{a}}$ & $4.67^{\mathrm{a}}$ & $3.20^{\mathrm{b}}$ & $6.83^{a}$ & $6.69^{a}$ & $6.55^{\mathrm{a}}$ & $8.59^{\mathrm{a}}$ \\
\hline \multicolumn{11}{|l|}{ Esters } \\
\hline Ethyl butanoate & $20[54]$ & $\begin{array}{c}\text { Pineapple, } \\
\text { apple, peach } \\
\text { [57] }\end{array}$ & $174.39 \pm 1.16^{b}$ & $190.00 \pm 1.34^{a}$ & $65.44 \pm 1.63^{b}$ & $77.66 \pm 0.05^{a}$ & $166.28 \pm 4.18^{a}$ & $106.34 \pm 0.49^{b}$ & $142.49 \pm 4.12^{\mathrm{a}}$ & $127.40 \pm 14.59^{a}$ \\
\hline
\end{tabular}


Table 2. Cont.

\begin{tabular}{|c|c|c|c|c|c|c|c|c|c|c|}
\hline & ODT $(\mu g / L)$ & $\begin{array}{c}\text { Odor } \\
\text { Descriptor }\end{array}$ & $\begin{array}{c}\text { Babić } \\
\text { Control }\end{array}$ & $\begin{array}{c}\text { Babić } \\
\text { Lachancea }\end{array}$ & $\begin{array}{l}\text { Blatina } \\
\text { Control }\end{array}$ & $\begin{array}{c}\text { Blatina } \\
\text { Lachancea }\end{array}$ & $\begin{array}{c}\text { Frankovka } \\
\text { Control }\end{array}$ & $\begin{array}{l}\text { Frankovka } \\
\text { Lachancea }\end{array}$ & $\begin{array}{l}\text { Trnjak } \\
\text { Control }\end{array}$ & $\begin{array}{c}\text { Trnjak } \\
\text { Lachancea }\end{array}$ \\
\hline Ethyl decanoate & $200[62]$ & $\begin{array}{l}\text { Floral, grape, } \\
\text { fruity [59] }\end{array}$ & $12.97 \pm 0.45^{b}$ & $38.47 \pm 1.69^{a}$ & $18.07 \pm 0.81^{a}$ & $10.90 \pm 0.35^{b}$ & $28.38 \pm 0.71^{a}$ & $13.85 \pm 0.73^{b}$ & $28.47 \pm 0.14^{\mathrm{a}}$ & $9.20 \pm 2.30^{b}$ \\
\hline Ethyl furoate & $16,000[54]$ & & $0.23 \pm 0.04^{b}$ & $2.13 \pm 0.03^{\mathrm{a}}$ & $3.24 \pm 0.08^{a}$ & $0.06 \pm 0.01^{b}$ & $3.29 \pm 0.01^{\mathrm{a}}$ & $2.35 \pm 0.02^{b}$ & $1.94 \pm 1.25^{\mathrm{a}}$ & $1.54 \pm 0.16^{\mathrm{a}}$ \\
\hline Ethyl hexanoate & $14[61]$ & $\begin{array}{c}\text { Fruity, green } \\
\text { apple, banana } \\
{[59]}\end{array}$ & $346.14 \pm 1.05^{\mathrm{b}}$ & $403.95 \pm 1.88^{\mathrm{a}}$ & $76.55 \pm 1.51^{\mathrm{a}}$ & $69.89 \pm 0.28^{b}$ & $207.57 \pm 2.20^{a}$ & $204.53 \pm 0.83^{a}$ & $381.84 \pm 4.62^{\mathrm{a}}$ & $187.62 \pm 28.00^{b}$ \\
\hline $\begin{array}{l}\text { Ethyl hydrogen } \\
\text { succinate }\end{array}$ & & & $0.15 \pm 0.00^{b}$ & $20.03 \pm 0.62^{a}$ & $2707.20 \pm 2.91^{a}$ & $2395.19 \pm 0.53^{b}$ & $0.20 \pm 0.00^{b}$ & $5.93 \pm 0.06^{a}$ & $\underset{\mathrm{a}}{6361.92 \pm 117.27}$ & $2854.00 \underset{b}{ \pm} 906.31$ \\
\hline Ethyl lactate & $154,000[54]$ & Butter [57] & $1754.17 \pm 1.44^{b}$ & $2889.01 \pm 0.16^{a}$ & $3307.43 \pm 2.89^{a}$ & $3108.26 \pm 2.14^{a}$ & $1528.19 \pm 2.88^{b}$ & $\begin{array}{c}3189.99 \pm 15.93 \\
a\end{array}$ & $\underset{\mathrm{b}}{1844.03} \pm 58.14$ & $\underset{\mathrm{a}}{2419.02}+145.90$ \\
\hline Ethyl linalyl acetal & & & $0.48 \pm 0.01^{\mathrm{a}}$ & $0.26 \pm 0.01^{\mathrm{b}}$ & $0.25 \pm 0.01^{\mathrm{b}}$ & $0.44 \pm 0.02^{\mathrm{a}}$ & $0.65 \pm 0.06^{\mathrm{a}}$ & $0.54 \pm 0.01^{\mathrm{a}}$ & $0.37 \pm 0.09^{\mathrm{a}}$ & $0.36 \pm 0.15^{\mathrm{a}}$ \\
\hline Ethyl linoleate & & & $0.01 \pm 0.04^{b}$ & $0.45 \pm 0.01^{\mathrm{a}}$ & $0.44 \pm 0.01^{b}$ & $1.61 \pm 0.02^{\mathrm{a}}$ & $1.56 \pm 0.01^{\mathrm{a}}$ & $0.65 \pm 0.06^{b}$ & $0.29 \pm 0.55^{\mathrm{a}}$ & $0.72 \pm 0.20^{a}$ \\
\hline Ethyl octanoate & $580[62]$ & $\begin{array}{l}\text { Sweet, floral, } \\
\text { fruity, pear } \\
{[57]}\end{array}$ & $217.15 \pm 2.98^{b}$ & $367.23 \pm 2.76^{a}$ & $95.21 \pm 1.86^{\mathrm{a}}$ & $76.83 \pm 0.45^{b}$ & $187.34 \pm 0.03^{a}$ & $110.71 \pm 0.72^{b}$ & $249.47 \pm 2.11^{a}$ & $80.23 \pm 16.60^{b}$ \\
\hline Ethyl vanillate & 3000 [62] & $\begin{array}{c}\text { Creamy, } \\
\text { vanilla [59] }\end{array}$ & $0.01 \pm 0.03^{a}$ & $0.01 \pm 0.08^{a}$ & $0.28 \pm 0.02^{a}$ & $0.06 \pm 0.04^{b}$ & $0.04 \pm 0.01^{\mathrm{a}}$ & $0.08 \pm 0.01^{\mathrm{a}}$ & $0.04 \pm 0.02^{a}$ & $0.10 \pm 0.06^{a}$ \\
\hline $\begin{array}{c}\text { Ethyl-2-hydroxy- } \\
\text { 3-methyl } \\
\text { butanoate }\end{array}$ & & & $7.04 \pm 0.11^{b}$ & $31.11 \pm 0.24^{\mathrm{a}}$ & $11.75 \pm 0.56^{\mathrm{a}}$ & $10.91 \pm 0.39^{a}$ & $9.10 \pm 0.08^{a}$ & $6.57 \pm 0.02^{b}$ & $3.63 \pm 0.11^{\mathrm{a}}$ & $3.16 \pm 0.60^{a}$ \\
\hline $\begin{array}{l}\text { Ethyl-2- } \\
\text { methylbutanoate }\end{array}$ & $18[54]$ & $\begin{array}{c}\text { Apple, } \\
\text { strawberry } \\
{[59]}\end{array}$ & $6.17 \pm 0.16^{\mathrm{a}}$ & $1.19 \pm 0.09^{b}$ & $3.90 \pm 0.12^{\mathrm{a}}$ & $3.94 \pm 0.03^{\mathrm{a}}$ & $6.63 \pm 0.05^{\mathrm{a}}$ & $3.67 \pm 0.34^{b}$ & $1.80 \pm 0.47^{\mathrm{a}}$ & $1.90 \pm 0.45^{\mathrm{a}}$ \\
\hline $\begin{array}{c}\text { Ethyl-3- } \\
\text { hydroxybutanoate }\end{array}$ & $20,000[65]$ & $\begin{array}{l}\text { Grape, fruity, } \\
\text { caramel [70] }\end{array}$ & $30.00 \pm 0.27^{b}$ & $43.80 \pm 0.97^{\mathrm{a}}$ & $17.78 \pm 0.95^{\mathrm{a}}$ & $15.19 \pm 1.00^{\mathrm{a}}$ & $29.79 \pm 0.63^{a}$ & $12.95 \pm 0.46^{\mathrm{b}}$ & $31.34 \pm 0.38^{a}$ & $12.86 \pm 3.63^{b}$ \\
\hline $\begin{array}{c}\text { Ethyl-3- } \\
\text { methylbutanoate }\end{array}$ & $3[54]$ & $\begin{array}{c}\text { Fruity, } \\
\text { pineapple [47] }\end{array}$ & $9.31 \pm 0.04^{\mathrm{a}}$ & $5.52 \pm 0.04^{b}$ & $6.55 \pm 0.06^{\mathrm{a}}$ & $6.33 \pm 0.01^{b}$ & $21.31 \pm 0.67^{\mathrm{a}}$ & $7.45 \pm 0.28^{b}$ & $4.40 \pm 0.31^{\mathrm{a}}$ & $3.99 \pm 0.66^{a}$ \\
\hline Isoamyl acetate & $30[61]$ & Banana [57] & $1017.78 \pm 2.05^{\mathrm{a}}$ & $886.04 \pm 0.78^{b}$ & $527.92 \pm 1.85^{\mathrm{a}}$ & $478.02 \pm 0.70^{b}$ & $2276.20 \pm 0.98^{a}$ & $1456.07 \pm 1.24^{b}$ & $661.26 \pm 19.59^{a}$ & $597.79 \pm 52.38^{b}$ \\
\hline Isobutyl acetate & 6140 [57] & $\begin{array}{c}\text { Apple, banana } \\
\text { [59] }\end{array}$ & $42.57 \pm 1.00^{\mathrm{a}}$ & $48.36 \pm 1.62^{a}$ & $57.91 \pm 0.33^{a}$ & $53.54 \pm 1.01^{b}$ & $67.15 \pm 0.59^{b}$ & $76.71 \pm 0.73^{a}$ & $35.41 \pm 3.49^{b}$ & $81.15 \pm 2.91^{a}$ \\
\hline Hexyl acetate & $670[56]$ & $\begin{array}{l}\text { Fruity, green, } \\
\text { sweet [59] }\end{array}$ & $35.55 \pm 1.37^{a}$ & $12.21 \pm 1.35^{\mathrm{b}}$ & $3.30 \pm 0.05^{\mathrm{a}}$ & $3.02 \pm 0.04^{\mathrm{b}}$ & $9.59 \pm 0.71^{\mathrm{a}}$ & $10.70 \pm 0.50^{\mathrm{a}}$ & $15.94 \pm 1.16^{b}$ & $28.79 \pm 1.94^{\mathrm{a}}$ \\
\hline Methyl vanillate & & & $9.46 \pm 0.05^{\mathrm{a}}$ & $8.65 \pm 0.05^{b}$ & $0.01 \pm 0.00^{\mathrm{a}}$ & $0.02 \pm 0.01^{\mathrm{a}}$ & $77.75 \pm 0.71^{b}$ & $80.97 \pm 0.37^{a}$ & $21.71 \pm 0.34^{\mathrm{a}}$ & $21.51 \pm 3.64^{\mathrm{a}}$ \\
\hline
\end{tabular}


Table 2. Cont.

\begin{tabular}{|c|c|c|c|c|c|c|c|c|c|c|}
\hline & ODT $(\mu \mathrm{g} / \mathrm{L})$ & $\begin{array}{c}\text { Odor } \\
\text { Descriptor }\end{array}$ & $\begin{array}{c}\text { Babić } \\
\text { Control }\end{array}$ & $\begin{array}{c}\text { Babić } \\
\text { Lachancea }\end{array}$ & $\begin{array}{l}\text { Blatina } \\
\text { Control }\end{array}$ & $\begin{array}{c}\text { Blatina } \\
\text { Lachancea }\end{array}$ & $\begin{array}{c}\text { Frankovka } \\
\text { Control }\end{array}$ & $\begin{array}{l}\text { Frankovka } \\
\text { Lachancea }\end{array}$ & $\begin{array}{c}\text { Trnjak } \\
\text { Control }\end{array}$ & $\begin{array}{c}\text { Trnjak } \\
\text { Lachancea }\end{array}$ \\
\hline $\begin{array}{l}\text { Geranium acid } \\
\text { methyl ester }\end{array}$ & & & $4.65 \pm 0.08^{\mathrm{a}}$ & $3.47 \pm 0.01^{b}$ & $0.01 \pm 0.00^{\mathrm{a}}$ & $0.01 \pm 0.01^{\mathrm{a}}$ & $6.42 \pm 0.30^{a}$ & $4.45 \pm 0.40^{b}$ & $3.30 \pm 0.13^{\mathrm{a}}$ & $3.04 \pm 1.09^{\mathrm{a}}$ \\
\hline Diethyl malate & & & $40.82 \pm 0.89^{a}$ & $20.63 \pm 0.85^{b}$ & $67.72 \pm 0.81^{\mathrm{a}}$ & $62.87 \pm 0.68^{b}$ & $19.69 \pm 0.85^{a}$ & $15.75 \pm 0.69^{b}$ & $45.87 \pm 2.59^{b}$ & $80.58 \pm 8.91^{a}$ \\
\hline Diethyl succinate & $200,000[37]$ & $\begin{array}{l}\text { Overripe, } \\
\text { aged [55] }\end{array}$ & $438.85 \pm 0.83^{b}$ & $865.90 \pm 5.18^{a}$ & $434.01 \pm 1.80^{a}$ & $408.95 \pm 0.84^{b}$ & $473.02 \pm 0.77^{a}$ & $171.29 \pm 18.46^{b}$ & $428.85 \pm 9.81^{a}$ & $340.64 \pm 38.95^{b}$ \\
\hline$\Sigma$ & & & $4148.45^{\mathrm{b}}$ & $5839.52^{a}$ & $7418.19^{a}$ & $6795.92^{b}$ & $5120.67^{b}$ & $5482.20^{\mathrm{a}}$ & $10,280.21^{a}$ & $6952.26^{b}$ \\
\hline \multicolumn{11}{|l|}{ Lactones } \\
\hline$\gamma$-Butirolactone & $10,000[57]$ & $\begin{array}{c}\text { Coconut, } \\
\text { caramel [43] }\end{array}$ & $477.88 \pm 2.38^{b}$ & $544.56 \pm 1.42^{\mathrm{a}}$ & $463.59 \pm 9.15^{a}$ & $463.10 \pm 0.22^{a}$ & $525.68 \pm 0.76^{b}$ & $721.52 \pm 0.86^{\mathrm{a}}$ & $235.97 \pm 23.02^{b}$ & $415.74 \pm 28.48^{a}$ \\
\hline$\gamma$-Decalactone & 1000 [57] & $\begin{array}{c}\text { Peach, fruity } \\
{[43]}\end{array}$ & $2.30 \pm 0.01^{\mathrm{a}}$ & $1.78 \pm 0.02^{\mathrm{b}}$ & $1.42 \pm 0.38^{\mathrm{b}}$ & $2.62 \pm 0.10^{\mathrm{a}}$ & $2.60 \pm 0.01^{b}$ & $10.73 \pm 0.79^{\mathrm{a}}$ & $1.88 \pm 0.52^{b}$ & $13.99 \pm 0.39^{a}$ \\
\hline$\gamma$-Hexalactone & 1600 [72] & $\begin{array}{l}\text { Sweet, cake, } \\
\text { peach [43] }\end{array}$ & $5.36 \pm 0.22^{a}$ & $5.12 \pm 0.04^{a}$ & $3.20 \pm 0.07^{\mathrm{a}}$ & $2.95 \pm 0.01^{\mathrm{b}}$ & $3.88 \pm 0.02^{\mathrm{a}}$ & $4.22 \pm 0.35^{\mathrm{a}}$ & $3.90 \pm 0.16^{\mathrm{b}}$ & $6.44 \pm 0.41^{\mathrm{a}}$ \\
\hline$\gamma$-Nonalactone & 25 [49] & $\begin{array}{c}\text { Coconut, } \\
\text { peach [43] }\end{array}$ & $24.00 \pm 0.27^{a}$ & $19.31 \pm 0.02^{b}$ & $27.96 \pm 0.64^{a}$ & $27.25 \pm 1.73^{a}$ & $22.19 \pm 0.71^{a}$ & $14.92 \pm 0.93^{b}$ & $53.18 \pm 1.31^{\mathrm{a}}$ & $39.68 \pm 6.15^{b}$ \\
\hline$\gamma$-Octalactone & $7[49]$ & & $2.30 \pm 0.01^{\mathrm{a}}$ & $0.74 \pm 0.02^{b}$ & $2.26 \pm 0.01^{\mathrm{a}}$ & $1.72 \pm 0.01^{b}$ & $2.39 \pm 0.38^{\mathrm{a}}$ & $0.98 \pm 0.01^{b}$ & $1.11 \pm 2.01^{\mathrm{a}}$ & $3.16 \pm 0.65^{\mathrm{a}}$ \\
\hline$\gamma$-Undecalactone & 60 [49] & $\begin{array}{c}\text { Apricot, peach } \\
\text { [47] }\end{array}$ & $0.56 \pm 0.04^{\mathrm{a}}$ & $0.36 \pm 0.04^{b}$ & $0.56 \pm 0.01^{\mathrm{a}}$ & $0.34 \pm 0.01^{b}$ & $0.53 \pm 0.05^{\mathrm{a}}$ & $0.66 \pm 0.01^{\mathrm{a}}$ & $0.44 \pm 0.03^{b}$ & $0.81 \pm 0.09^{\mathrm{a}}$ \\
\hline$\delta$-Decalactone & & & $3.54 \pm 0.01^{\mathrm{a}}$ & $3.37 \pm 0.26^{\mathrm{a}}$ & $2.90 \pm 0.01^{\mathrm{a}}$ & $2.77 \pm 0.01^{b}$ & $3.39 \pm 0.23^{a}$ & $1.99 \pm 0.16^{b}$ & $4.11 \pm 0.11^{\mathrm{a}}$ & $2.76 \pm 0.68^{b}$ \\
\hline$\Sigma$ & & & $515.93^{b}$ & $575.24^{a}$ & $501.88^{a}$ & $500.74^{a}$ & $560.64^{b}$ & $755.00^{a}$ & $300.57^{b}$ & $482.57^{\mathrm{a}}$ \\
\hline \multicolumn{11}{|l|}{ Fatty acids } \\
\hline Butanoic acid & 400 [55] & $\begin{array}{c}\text { Rancid, } \\
\text { cheesy [43] }\end{array}$ & $56.80 \pm 0.12^{a}$ & $69.13 \pm 0.61^{\mathrm{a}}$ & $220.62 \pm 0.75^{\mathrm{a}}$ & $223.53 \pm 3.06^{\mathrm{a}}$ & $50.25 \pm 0.76^{\mathrm{a}}$ & $33.28 \pm 0.52^{b}$ & $526.76 \pm 16.87^{a}$ & $628.68 \pm \underset{a}{a} 105.07$ \\
\hline Heptanoic acid & $3000[53]$ & $\begin{array}{c}\text { Rancid, } \\
\text { cheesy [43] }\end{array}$ & $13.05 \pm 0.42^{\mathrm{a}}$ & $11.69 \pm 0.68^{a}$ & $9.61 \pm 0.18^{a}$ & $8.76 \pm 0.29^{a}$ & $5.32 \pm 0.45^{b}$ & $13.64 \pm 0.68^{a}$ & $17.56 \pm 0.35^{\mathrm{a}}$ & $14.38 \pm 1.82^{\mathrm{b}}$ \\
\hline Hexanoic acid & 420 [53] & $\begin{array}{c}\text { Cheesy, oily } \\
\text { [57] }\end{array}$ & $\begin{array}{c}1261.73 \pm 41.87 \\
\mathrm{~b}\end{array}$ & $1420.06 \pm 1.02^{\mathrm{a}}$ & $546.11 \pm 1.05^{\mathrm{a}}$ & $513.36 \pm 1.12^{b}$ & $707.79 \pm 0.63^{a}$ & $570.43 \pm 0.95^{b}$ & $\underset{\mathrm{a}}{1929.66 \pm 23.44}$ & $\underset{\mathrm{b}}{1045.24 \pm 407.61}$ \\
\hline Isovaleric acid & $33[61]$ & $\begin{array}{c}\text { Sweet, rancid } \\
\text { [43] }\end{array}$ & $4.50 \pm 0.23^{b}$ & $6.13 \pm 0.01^{\mathrm{a}}$ & $3.06 \pm 0.02^{a}$ & $3.19 \pm 0.01^{\mathrm{a}}$ & $5.53 \pm 0.68^{a}$ & $3.76 \pm 0.10^{\mathrm{a}}$ & $3.33 \pm 0.36^{a}$ & $3.14 \pm 0.40^{\mathrm{a}}$ \\
\hline
\end{tabular}


Table 2. Cont.

\begin{tabular}{|c|c|c|c|c|c|c|c|c|c|c|}
\hline & ODT $(\mu \mathrm{g} / \mathrm{L})$ & $\begin{array}{c}\text { Odor } \\
\text { Descriptor }\end{array}$ & $\begin{array}{l}\text { Babić } \\
\text { Control }\end{array}$ & $\begin{array}{c}\text { Babić } \\
\text { Lachancea }\end{array}$ & $\begin{array}{l}\text { Blatina } \\
\text { Control }\end{array}$ & $\begin{array}{c}\text { Blatina } \\
\text { Lachancea }\end{array}$ & $\begin{array}{c}\text { Frankovka } \\
\text { Control }\end{array}$ & $\begin{array}{l}\text { Frankovka } \\
\text { Lachancea }\end{array}$ & $\begin{array}{l}\text { Trnjak } \\
\text { Control }\end{array}$ & $\begin{array}{c}\text { Trnjak } \\
\text { Lachancea }\end{array}$ \\
\hline Octanoic acid & $500[54]$ & $\begin{array}{c}\text { Rancid, oily } \\
\text { [59] }\end{array}$ & $1185.08 \pm 0.49^{b}$ & $1394.94 \pm 3.65^{\mathrm{a}}$ & $430.56 \pm 0.98^{a}$ & $402.15 \pm 1.41^{b}$ & $724.85 \pm 2.14^{a}$ & $506.16 \pm 1.13^{b}$ & $\begin{array}{c}1655.69 \pm 16.56 \\
a\end{array}$ & $511.98 \pm 354.13$ \\
\hline Decanoic acid & 1000 [71] & $\begin{array}{c}\text { Rancid, waxy } \\
\text { [43] }\end{array}$ & $8.37 \pm 0.03^{b}$ & $149.26 \pm 1.29^{a}$ & $5.89 \pm 0.09^{b}$ & $137.57 \pm 2.79^{a}$ & $7.23 \pm 0.07^{\mathrm{a}}$ & $6.90 \pm 0.13^{a}$ & $361.78 \pm 1.75^{a}$ & $96.62 \pm 82.42^{b}$ \\
\hline $\begin{array}{l}2- \\
\text { Methylpropionic } \\
\text { acid }\end{array}$ & & & $1168.90 \pm 0.54^{\mathrm{b}}$ & $1281.00 \pm 0.64^{\mathrm{a}}$ & $975.71 \pm 0.74^{\mathrm{a}}$ & $929.75 \pm 1.13^{b}$ & $2050.21 \pm 1.27^{\mathrm{b}}$ & $\begin{array}{c}5175.83 \pm 52.74 \\
\text { a }\end{array}$ & $704.78 \pm 72.86^{\mathrm{b}}$ & $\underset{\mathrm{a}}{2457.96} \pm 145.03$ \\
\hline$\Sigma$ & & & $4226,30^{b}$ & $4368.78^{a}$ & $2210.54^{a}$ & $2231.17^{a}$ & $3568.59^{b}$ & $6344.59^{a}$ & $4833.16^{a}$ & $5258.74^{a}$ \\
\hline \multicolumn{11}{|l|}{ Other alcohols } \\
\hline 1,4-Butanediol & & & $1.03 \pm 0.03^{\mathrm{a}}$ & $3.33 \pm 0.03^{\mathrm{a}}$ & $0.52 \pm 0.05^{\mathrm{a}}$ & $0.55 \pm 0.01^{\mathrm{a}}$ & $0.36 \pm 0.03^{b}$ & $29.22 \pm 14.21^{a}$ & $1.31 \pm 0.13^{b}$ & $2.91 \pm 0.33^{\mathrm{a}}$ \\
\hline $\begin{array}{c}4- \\
\text { Ethylcyclohexanol }\end{array}$ & & & $3.13 \pm 0.18^{\mathrm{a}}$ & $1.98 \pm 0.01^{\mathrm{b}}$ & $4.38 \pm 0.01^{\mathrm{a}}$ & $3.67 \pm 0.01^{b}$ & $1.60 \pm 0.11^{\mathrm{a}}$ & $0.97 \pm 0.04^{b}$ & $7.30 \pm 0.26^{a}$ & $5.19 \pm 0.83^{b}$ \\
\hline $\begin{array}{l}\text { 4-Methyl-1- } \\
\text { pentanol }\end{array}$ & $50,000[57]$ & $\begin{array}{c}\text { Almond, } \\
\text { toasted [47] }\end{array}$ & $32.27 \pm 1.38^{a}$ & $38.05 \pm 1.42^{\mathrm{a}}$ & $32.67 \pm 0.74^{a}$ & $30.85 \pm 0.47^{\mathrm{a}}$ & $82.99 \pm 0.48 \mathrm{a}$ & $35.19 \pm 0.40^{b}$ & $23.06 \pm 0.67^{b}$ & $32.45 \pm 4.95^{\mathrm{a}}$ \\
\hline Benzylalcohol & $10,000[63]$ & $\begin{array}{l}\text { Roasted, } \\
\text { toasted, sweet, } \\
\text { fruity [43] }\end{array}$ & $17.25 \pm 0.63^{b}$ & $20.65 \pm 0.61^{a}$ & $8.73 \pm 0.01^{b}$ & $9.22 \pm 0.09^{a}$ & $48.97 \pm 0.12^{\mathrm{a}}$ & $50.62 \pm 0.56^{\mathrm{a}}$ & $16.61 \pm 1.34^{a}$ & $14.52 \pm 2.03^{a}$ \\
\hline$\Sigma$ & & & $55.20^{\mathrm{b}}$ & $65.95^{a}$ & $47.29^{a}$ & $45.21^{a}$ & $135.24^{\mathrm{a}}$ & $116.31^{a}$ & $53.73^{a}$ & $56.98^{a}$ \\
\hline \multicolumn{11}{|l|}{$\begin{array}{c}\text { Other } \\
\text { compounds }\end{array}$} \\
\hline Acetoin & $150,000[54]$ & $\begin{array}{c}\text { Buttery, } \\
\text { creamy [57] }\end{array}$ & $17.26 \pm 0.82^{b}$ & $71.91 \pm 0.33^{a}$ & $63.05 \pm 0.19^{a}$ & $65.95 \pm 0.95^{\mathrm{a}}$ & $13.57 \pm 1.66^{\mathrm{b}}$ & $21.02 \pm 1.17^{\mathrm{a}}$ & $41.39 \pm 1.36^{\mathrm{a}}$ & $30.82 \pm 4.74^{\mathrm{a}}$ \\
\hline Acetylfurane & & & $0.56 \pm 0.01^{b}$ & $0.85 \pm 0.05^{\mathrm{a}}$ & $1.82 \pm 0.05^{\mathrm{a}}$ & $1.55 \pm 0.21^{\mathrm{a}}$ & $1.28 \pm 0.07^{\mathrm{a}}$ & $1.57 \pm 0.03^{\mathrm{a}}$ & $0.77 \pm 0.67^{\mathrm{a}}$ & $0.85 \pm 0.40^{\mathrm{a}}$ \\
\hline $\begin{array}{l}\text { 2H-Pyran-2,6(3H)- } \\
\text { dione }\end{array}$ & & & $59.45 \pm 0.77^{b}$ & $71.65 \pm 0.91^{a}$ & $46.21 \pm 0.52^{\mathrm{a}}$ & $37.07 \pm 1.00^{b}$ & $70.63 \pm 0.59^{a}$ & $62.16 \pm 1.32^{b}$ & $58.86 \pm 1.95^{a}$ & $38.03 \pm 6.98^{b}$ \\
\hline 2-Pentylfuran & 2000 [64] & & $260.59 \pm 1.61^{b}$ & $329.93 \pm 0.34^{a}$ & $243.75 \pm 2.16^{a}$ & $247.47 \pm 1.10^{\mathrm{a}}$ & $355.53 \pm 1.60^{\mathrm{a}}$ & $358.77 \pm 0.48^{\mathrm{a}}$ & $285.39 \pm 3.23^{a}$ & $251.00 \pm 5.41^{a}$ \\
\hline$\Sigma$ & & & $337.86^{b}$ & $474.34^{\mathrm{a}}$ & $354.83^{a}$ & $352.04^{a}$ & $441.01^{\mathrm{a}}$ & $443.52^{a}$ & $386.41^{a}$ & $320.70^{b}$ \\
\hline ODT_-odor det & threshold & & & & & & & & & \\
\hline
\end{tabular}




\subsection{Odor Active Values (OAVs) and Relative Odor Contributions (ROCs)}

To evaluate the influence of individual volatile compounds on the overall aroma of each red variety of wine, OAVs and ROC indexes were calculated and are presented in Table 2. From a total of 122 compounds, only 17 exceeded the threshold values (OAV > 1). Between them, the most abundant were esters, with four individual compounds, followed by terpenes, aldehydes, and fatty acids, with three compounds each, and higher alcohols, volatile phenols, C13-norisoprenoides, and lactones, with only one compound each. In Babić wines, the highest OAV was $\beta$-damascenone, with no marked ROC differences between control and sequential fermentation wines. The use of L. thermotolerans in Babić wines positively influenced total ester, terpene, and fatty acid ROCs with higher ethyl hexanoate, linalool, hexanoic, and octanoic acid OAVs. The ROC of isoamyl acetate was noted in all wines, but especially in Frankovka and Babić control wines. Comparing OAVs in Blatina wines, the highest one was connected with $\beta$-damascenone, with higher values in control wine, while the strong influence of sequential fermentation was noted with the presence of aldehydes, especially decanal, which resulted in an almost $10 \%$ higher total ROC. Blatina wines produced with the use of $L$. thermotolerans also stood up with higher total fatty acid and total ester ROCs as well as $\gamma$-nonalactone and eugenol values. On the contrary, in Frankovka and Trnjak wines, the total ROC of esters, fatty acids, terpenes, $\gamma$-nonalactone, and eugenol was stronger in control variants, while $L$. thermotolerans positively influenced total aldehydes and $\beta$-damascenone OAV, especially in Trnjak wines.

\section{Conclusions}

In conclusion, the data from the presented work pointed out positive effects of $L$. thermotolerans yeast on overall wine composition, although they were different between the varieties used. For the first time, the influence of an equal sequential fermentation strategy was applied in the production of four different grape varieties of wines. The resulting production of L-lactic acid regardless of primary grape must composition pointed out the use of $L$. thermotolerans as an effective acidification tool of the fermenting grape must as well as a possible path for reduction of wine alcohol content. In Babić wines, the strongest influence of sequential fermentation was connected with higher total terpene and total ester concentrations, mainly due to the higher farnesol, linalool, neral, geraniol, and geranyl acetate presence, and due to the concentrations of mostly all ethyl esters being above the odor detection threshold, such as ethyl decanoate, ethyl octanoate, and ethyl hexanoate. Blatina sequentially fermented wines can be singled out by higher concentrations of some individual terpenes, such as geraniol, geranyl acetate, neral, and 1,8 terpin but a lower concentration of total esters and ethyl lactate, whose presence was significantly higher in Babić, Frankovka, and Trnjak wines. Significantly higher concentrations of ethyl lactate, together with some already mentioned individual terpenes, were present in Frankovka sequentially fermented wines, while Trnjak sequentially fermented wines stood up with higher total aldehyde volatile phenols and total lactone concentrations. Control wines, regardless of variety, stood up with higher concentrations of total higher alcohols, among them especially isoamyl alcohol. In addition, higher concentrations of citronellol, isoamyl acetate, and vanillin were defined in all control wines, as were total esters in Blatina and Frankovka wines. Thus, the most significantly different profiles between $S$. cerevisiae yeast fermentation and sequential fermentations were observed in total aldehyde, higher alcohol, ester, and terpene concentrations. Our data also showed that multivariate analysis differences in the volatile aroma compounds can be a useful tool leading to an optimal selection of yeasts with the main purpose of producing high-quality varietal wines.

Supplementary Materials: The following are available online at https:/ / www.mdpi.com/2311-563 7/7/1/4/s1, Table S1: Identification and quantification parameters for GC-MS analysis. 
Author Contributions: Conceptualization, A.-M.J.K. and A.J.; methodology, B.Š. and I.T.; formal analysis, M.L. and I.T.; data curation, D.P.; writing—original draft preparation, A.-M.J.K.; writingreview and editing, A.-M.J.K. and D.P.; supervision, A.J. All authors have read and agreed to the published version of the manuscript.

Funding: Financial support for this work is attributed to the project, KK.01.1.1.04.0031, New Start for Croatian Grapevine Varieties (CroVitiRestart) funded by European Structural and Investment Funds and the Croatian Ministry of Science and Education.

Data Availability Statement: Data available on request due to restrictions eg privacy or ethical. The data presented in this study are available on request from the corresponding author. The data are not publicly available there are part of PhD thesis.

Conflicts of Interest: The authors declare no conflict of interest.

\section{References}

1. Belda, I.; Ruiz, J.; Esteban-Fernández, A.; Navascués, E.; Marquina, D.; Santos, A.; Moreno-Arribas, M.V. Microbial contribution to Wine aroma and its intended use for Wine quality improvement. Molecules 2017, 22, 189. [CrossRef] [PubMed]

2. Liu, P.T.; Lu, L.; Duan, C.Q.; Yan, G.L. The contribution of indigenous non-Saccharomyces wine yeast to improved aromatic quality of Cabernet Sauvignon wines by spontaneous fermentation. LWT Food Sci. Technol. 2016, 71, 356-363. [CrossRef]

3. Saberi, S.; Cliff, M.A.; van Vuuren, H.J.J. Impact of mixed S. cerevisiae strains on the production of volatiles and estimated sensory profiles of Chardonnay wines. Food Res. Int. 2012, 48, 725-735. [CrossRef]

4. Padilla, B.; Gil, J.V.; Manzanares, P. Past and future of non-Saccharomyces yeasts: From spoilage microorganisms to biotechnological tools for improving wine aroma complexity. Front. Microbiol. 2016, 7, 411. [CrossRef]

5. Ciani, M.; Morales, P.; Comitini, F.; Tronchoni, J.; Canonico, L.; Curiel, J.A.; Oro, L.; Rodrigues, A.J.; Gonzalez, R. Non-conventional yeast species for lowering ethanol content of wines. Front. Microbiol. 2016, 7, 642. [CrossRef]

6. Gatto, V.; Binati, R.L.; Lemos Junior, W.J.F.; Basile, A.; Treu, L.; de Almeida, O.G.G.; Innocente, G.; Campanaro, S.; Torriani, S. New insights into the variability of lactic acid production in Lachancea thermotolerans at the phenotypic and genomic level. Microbiol. Res. 2020, 238, 126525. [CrossRef]

7. Binati, R.L.; Lemos Junior, W.J.F.; Luzzini, G.; Slaghenaufi, D.; Ugliano, M.; Torriani, S. Contribution of non-Saccharomyces yeasts to wine volatile and sensory diversity: A study on Lachancea thermotolerans, Metschnikowia spp. and Starmerella bacillaris strains isolated in Italy. Int. J. Food Microbiol. 2020, 318, 108470. [CrossRef]

8. Porter, T.J.; Divol, B.; Setati, M.E. Investigating the biochemical and fermentation attributes of Lachancea species and strains: Deciphering the potential contribution to wine chemical composition. Int. J. Food Microbiol. 2019, 290, 273-287. [CrossRef]

9. Gobbi, M.; Comitini, F.; Domizio, P.; Romani, C.; Lencioni, L.; Mannazzu, I.; Ciani, M. Lachancea thermotolerans and Saccharomyces cerevisiae in simultaneous and sequential co-fermentation: A strategy to enhance acidity and improve the overall quality of wine. Food Microbiol. 2013, 33, 271-281. [CrossRef]

10. Kapsopoulou, K.; Mourtzini, A.; Anthoulas, M.; Nerantzis, E. Biological acidification during grape must fermentation using mixed cultures of Kluyveromyces thermotolerans and Saccharomyces cerevisiae. World J. Microbiol. Biotechnol. 2007, 23, 735-739. [CrossRef]

11. Beckner Whitener, M.E.; Carlin, S.; Jacobson, D.; Weighill, D.; Divol, B.; Conterno, L.; Du Toit, M.; Vrhovsek, U. Early fermentation volatile metabolite profile of non-Saccharomyces yeasts in red and white grape must: A targeted approach. LWT Food Sci. Technol. 2015, 64, 412-422. [CrossRef]

12. Whitener, M.E.B.; Stanstrup, J.; Carlin, S.; Divol, B.; Du Toit, M.; Vrhovsek, U. Effect of non-Saccharomyces yeasts on the volatile chemical profile of Shiraz wine. Aust. J. Grape Wine Res. 2017, 23, 179-192. [CrossRef]

13. Beckner Whitener, M.E.; Stanstrup, J.; Panzeri, V.; Carlin, S.; Divol, B.; Du Toit, M.; Vrhovsek, U. Untangling the wine metabolome by combining untargeted SPME-GCxGC-TOF-MS and sensory analysis to profile Sauvignon blanc co-fermented with seven different yeasts. Metabolomics 2016, 12, 53. [CrossRef]

14. OIV Standard for International Wine and Spirituous Beverages of Vitivinicultural Origin; International Organisation of Vine and Wine: Paris, France, 2009.

15. Jagatić Korenika, A.M.; Preiner, D.; Tomaz, I.; Jeromel, A. Volatile Profile Characterization of Croatian Commercial Sparkling Wines. Molecules 2020, 25, 4349. [CrossRef]

16. Falqué, E.; Fernández, E.; Dubourdieu, D. Differentiation of white wines by their aromatic index. Talanta 2001, 54, 271-281. [CrossRef]

17. Allen, M.S.; Lacey, M.J.; Boyd, S. Determination of Methoxypyrazines in Red Wines by Stable Isotope Dilution Gas ChromatographyMass Spectrometry. J. Agric. Food Chem. 1994, 42, 1734-1738. [CrossRef]

18. Francis, I.L.; Newton, J.L. Determining wine aroma from compositional data. Aust. J. Grape Wine Res. 2005, 11, 114-126. [CrossRef]

19. Ohloff, G. The Fashion of Odors and Their Chemical Perspectives: Scent and Fragrances; Springer: Berlin, Germany, 1994.

20. Benito, S.; Hofmann, T.; Laier, M.; Lochbühler, B.; Schüttler, A.; Ebert, K.; Fritsch, S.; Röcker, J.; Rauhut, D. Effect on quality and composition of Riesling wines fermented by sequential inoculation with non-Saccharomyces and Saccharomyces cerevisiae. Eur. Food Res. Technol. 2015, 241, 707-717. [CrossRef] 
21. Sgouros, G.; Mallouchos, A.; Filippousi, M.E.; Banilas, G.; Nisiotou, A. Molecular characterization and enological potential of a high lactic acid-producing lachancea thermotolerans vineyard strain. Foods 2020, 9, 595. [CrossRef]

22. Ferreira, A.M.; Mendes-Faia, A. The role of yeasts and lactic acid bacteria on the metabolism of organic acids during winemaking. Foods 2019, 9, 1231. [CrossRef]

23. Jones, G.V.; White, M.A.; Cooper, O.R.; Storchmann, K. Climate change and global wine quality. Clim. Chang. 2005, 73, 319-343. [CrossRef]

24. Field, S.J.; Ryden, P.; Wilson, D.; James, S.A.; Roberts, I.N.; Richardson, D.J.; Waldron, K.W.; Clarke, T.A. Identification of furfural resistant strains of Saccharomyces cerevisiae and Saccharomyces paradoxus from a collection of environmental and industrial isolates. Biotechnol. Biofuels 2015, 8, 33. [CrossRef] [PubMed]

25. Modig, T.; Lidén, G.; Taherzadeh, M.J. Inhibition effects of furfural on alcohol dehydrogenase, aldehyde dehydrogenase and pyruvate dehydrogenase. Biochem. J. 2002, 363, 769-776. [CrossRef] [PubMed]

26. Taherzadeh, M.J.; Gustafsson, L.; Niklasson, C.; Lidén, G. Conversion of furfural in aerobic and anaerobic batch fermentation of glucose by Saccharomyces cerevisiae. J. Biosci. Bioeng. 1999, 87, 169-174. [CrossRef]

27. Comitini, F.; Gobbi, M.; Domizio, P.; Romani, C.; Lencioni, L.; Mannazzu, I.; Ciani, M. Selected non-Saccharomyces wine yeasts in controlled multistarter fermentations with Saccharomyces cerevisiae. Food Microbiol. 2011, 28, 873-882. [CrossRef]

28. Fernández, M.; Úbeda, J.F.; Briones, A.I. Typing of non-Saccharomyces yeasts with enzymatic activities of interest in wine-making. Int. J. Food Microbiol. 2000, 59, 29-36. [CrossRef]

29. Cordero-Bueso, G.; Esteve-Zarzoso, B.; Cabellos, J.M.; Gil-Díaz, M.; Arroyo, T. Biotechnological potential of non-Saccharomyces yeasts isolated during spontaneous fermentations of Malvar (Vitis vinifera cv. L.). Eur. Food Res. Technol. 2013, 236, 193-207. [CrossRef]

30. Slegers, A.; Angers, P.; Ouellet, É.; Truchon, T.; Pedneault, K. Volatile compounds from grape skin, juice and wine from five interspecific hybrid grape cultivars grown in Québec (Canada) for wine production. Molecules 2015, 20, 10980-11016. [CrossRef]

31. Escribano, R.; González-Arenzana, L.; Portu, J.; Garijo, P.; López-Alfaro, I.; López, R.; Santamaría, P.; Gutiérrez, A.R. Wine aromatic compound production and fermentative behaviour within different non-Saccharomyces species and clones. J. Appl. Microbiol. 2018, 124, 1521-1531. [CrossRef]

32. Chen, K.; Escott, C.; Loira, I.; del Fresno, J.M.; Morata, A.; Tesfaye, W.; Calderon, F.; Suárez-Lepe, J.A.; Han, S.; Benito, S. Use of non-Saccharomyces yeasts and oenological tannin in red winemaking: Influence on colour, aroma and sensorial properties of young wines. Food Microbiol. 2018, 69, 51-63. [CrossRef]

33. Benito, Á.; Calderón, F.; Palomero, F.; Benito, S. Quality and composition of airén wines fermented by sequential inoculation of lachancea thermotolerans and saccharomyces cerevisiae. Food Technol. Biotechnol. 2016, 54, 135-144. [CrossRef] [PubMed]

34. Louw, L.; Tredoux, A.G.J.; van Rensburg, P.; Kidd, M.; Naes, T.; Nieuwoudt, H.H. Fermentation-derived aroma compounds in varietal young wines from South Africa. S. Afr. J. Enol. Vitic. 2010, 31, 213-225. [CrossRef]

35. Lukic, I.; Horvat, I. Differentiation of commercial PDO wines produced in istria (Croatia) according to variety and harvest year based on HS-SPME-GC/MS volatile aroma compound profi ling. Food Technol. Biotechnol. 2017, 55, 95-108. [CrossRef] [PubMed]

36. Gallardo-Chacón, J.J.; Vichi, S.; Urpí, P.; López-Tamames, E.; Buxaderas, S. Antioxidant activity of lees cell surface during sparkling wine sur lie aging. Int. J. Food Microbiol. 2010, 143, 48-53. [CrossRef] [PubMed]

37. Shinohara, T. Gas chromatographic analysis of volatile fatty acids in wines. Agric. Biol. Chem. 1985, 49, 2211-2212. [CrossRef]

38. Pérez-Olivero, S.J.; Pérez-Pont, M.L.; Conde, J.E.; Pérez-Trujillo, J.P. Determination of lactones in wines by headspace solid-phase microextraction and gas chromatography coupled with mass spectrometry. J. Anal. Methods Chem. 2014, 2014, 863019. [CrossRef]

39. Ribéreau-Gayon, P.; Glories, Y.; Maujean, A.; Dubourdieu, D. Handbook of Enology: The Chemistry of Wine Stabilization and Treatments, 2nd ed.; John Wiley \& Sons, Ltd.: Hoboken, NJ, USA, 2006; Volume 2.

40. Jackson, R.S. Chemical constituents of grapes and wine. In Wine Science; Academic Press: Amsterdam, The Netherland, 2020; ISBN 9780128161180.

41. Nakamura, S.; Crowell, E.A.; Ough, C.S.; Totsuka, A. Quantitative Analysis of $\gamma$-Nonalactone in Wines and Its Threshold Determination. J. Food Sci. 1988, 53, 1243-1244. [CrossRef]

42. Šuklje, K.; Zhang, X.; Antalick, G.; Clark, A.C.; Deloire, A.; Schmidtke, L.M. Berry Shriveling Significantly Alters Shiraz (Vitis vinifera L.) Grape and Wine Chemical Composition. J. Agric. Food Chem. 2016, 64, 870-880. [CrossRef]

43. Ferreira, V.; Lopez, R. The actual and potential aroma of winemaking grapes. Biomolecules 2019, 9, 818. [CrossRef]

44. García-Carpintero, E.G.; Sánchez-Palomo, E.; Gallego, M.A.G.; González-Viñas, M.A. Volatile and sensory characterization of red wines from cv. Moravia Agria minority grape variety cultivated in La Mancha region over five consecutive vintages. Food Res. Int. 2011, 44, 1549-1560. [CrossRef]

45. D'Onofrio, C.; Matarese, F.; Cuzzola, A. Study of the terpene profile at harvest and during berry development of Vitis vinifera L. aromatic varieties Aleatico, Brachetto, Malvasia di Candia aromatica and Moscato bianco. J. Sci. Food Agric. 2017, 97, $2898-2907$. [CrossRef] [PubMed]

46. Zea, L.; Moyano, L.; Ruiz, M.J.; Medina, M. Chromatography-Olfactometry Study of the Aroma of Fino Sherry Wines. Int. J. Anal. Chem. 2010, 2010, 626298. [CrossRef] [PubMed]

47. Available online: www.thegoodscentcompany.com (accessed on 10 November 2020).

48. Pino, J.A.; Mesa, J. Contribution of volatile compounds to mango (Mangifera indica L.) aroma. Flavour Fragr. J. 2006, 21, 207-213. [CrossRef] 
49. Noguerol-Pato, R.; González-Álvarez, M.; González-Barreiro, C.; Cancho-Grande, B.; Simal-Gándara, J. Evolution of the aromatic profile in Garnacha Tintorera grapes during raisining and comparison with that of the naturally sweet wine obtained. Food Chem. 2013, 139, 1052-1061. [CrossRef] [PubMed]

50. Sacks, G.L.; Gates, M.J.; Ferry, F.X.; Lavin, E.H.; Kurtz, A.J.; Acree, T.E. Sensory threshold of 1,1,6-trimethyl-1,2-dihydronaphthalene (TDN) and concentrations in young Riesling and non-Riesling wines. J. Agric. Food Chem. 2012, 60, 2998-3004. [CrossRef]

51. Ferreira, V.; López, R.; Cacho, J.F. Quantitative determination of the odorants of young red wines from different grape varieties. J. Sci. Food Agric. 2000, 80, 1659-1667. [CrossRef]

52. Engel, K.H.; Flath, R.A.; Buttery, R.G.; Mon, T.R.; Teranishi, R.; Ramming, D.W. Investigation of volatile constituents in nectarines. 1. Analytical and sensory characterization of aroma components in some nectarine cultivars. J. Agric. Food Chem. 1988, 36, 549-553. [CrossRef]

53. Sonni, F.; Moore, E.G.; Chinnici, F.; Riponi, C.; Smyth, H.E. Characterisation of Australian Verdelho wines from the Queensland Granite Belt region. Food Chem. 2016, 196, 1163-1171. [CrossRef]

54. Fariña, L.; Villar, V.; Ares, G.; Carrau, F.; Dellacassa, E.; Boido, E. Volatile composition and aroma profile of Uruguayan Tannat wines. Food Res. Int. 2015, 69, 244-255. [CrossRef]

55. Ferreira, V.; Ortín, N.; Escudero, A.; López, R.; Cacho, J. Chemical characterization of the aroma of Grenache rosé wines: Aroma extract dilution analysis, quantitative determination, and sensory reconstitution studies. J. Agric. Food Chem. 2002, 50, $4048-4054$. [CrossRef]

56. Guth, H. Quantification and sensory studies of character impact odorants of different white wine varieties. J. Agric. Food Chem. 1997, 45, 3027-3032. [CrossRef]

57. Available online: http://www.leffingwell.com/odorthre.htm (accessed on 10 November 2020).

58. Fenoll, J.; Manso, A.; Hellín, P.; Ruiz, L.; Flores, P. Changes in the aromatic composition of the Vitis vinifera grape Muscat Hamburg during ripening. Food Chem. 2009, 114, 420-428. [CrossRef]

59. Zhao, P.; Gao, J.; Qian, M.; Li, H. Characterization of the key aroma compounds in Chinese syrah wine by gas chromatographyOlfactometry-Mass spectrometry and Aroma reconstitution studies. Molecules 2017, 22, 1045. [CrossRef] [PubMed]

60. Herrero, P.; Sáenz-Navajas, P.; Culleré, L.; Ferreira, V.; Chatin, A.; Chaperon, V.; Litoux-Desrues, F.; Escudero, A. Chemosensory characterization of Chardonnay and Pinot Noir base wines of Champagne. Two very different varieties for a common product. Food Chem. 2016, 207, 239-250. [CrossRef]

61. Van Gemert, L.J. Compilation of Odour Treshold Values in Air and Water; Oliemans Punter \& Partners BV: Zeist, The Netherland, 2011; ISBN 9789081089401.

62. Ohloff, G. Importance of minor components in flavors and fragrances. Perfum. Flavor 1978, 3, 11-22.

63. Moyano, L.; Chaves, M.; Zea, L. A Technical Alternative to Aging. J. Agric. Sci. Appl. 2012, 1, $116-121$.

64. Castro-Vázquez, L.; Díaz-Maroto, M.C.; Pérez-Coello, M.S. Aroma composition and new chemical markers of Spanish citrus honeys. Food Chem. 2007, 103, 601-606. [CrossRef]

65. Sáenz, C.; Cedrón, T.; Cabredo, S. Classification of wines from five Spanish origin denominations by aromatic compound analysis. J. AOAC Int. 2010, 93, 1916-1922. [CrossRef]

66. Yamamoto, T.; Matsuda, H.; Utsumi, Y.; Hagiwara, T.; Kanisawa, T. Synthesis and odor of optically active rose oxide. Tetrahedron Lett. 2002, 43, 9077-9080. [CrossRef]

67. Pardo, E.; Rico, J.; Gil, J.V.; Orejas, M. De novo production of six key grape aroma monoterpenes by a geraniol synthase-engineered S. cerevisiae wine strain. Microb. Cell Fact. 2015, 14, 136. [CrossRef]

68. Langen, J.; Wegmann-Herr, P.; Schmarr, H.G. Quantitative determination of $\alpha$-ionone, $\beta$-ionone, and $\beta$-damascenone and enantiodifferentiation of $\alpha$-ionone in wine for authenticity control using multidimensional gas chromatography with tandem mass spectrometric detection. Anal. Bioanal. Chem. 2016, 408, 6483-6496. [CrossRef] [PubMed]

69. Buttery, R.G.; Turnbaugh, J.G.; Ling, L.C. Contribution of volatiles to rice aroma. J. Agric. Food Chem. 1988, 36, 1006-1009. [CrossRef]

70. Mestre, M.V.; Maturano, Y.P.; Gallardo, C.; Combina, M.; Mercado, L.; Toro, M.E.; Carrau, F.; Vazquez, F.; Dellacassa, E. Impact on sensory and aromatic profile of low ethanol malbec wines fermented by sequential culture of Hanseniaspora uvarum and Saccharomyces cerevisiae native yeasts. Fermentation 2019, 5, 65. [CrossRef]

71. Takeoka, G.R.; Flath, R.A.; Mon, T.R.; Teranishi, R.; Guentert, M. Volatile Constituents of Apricot (Prunus Armeniaca). J. Agric. Food Chem. 1990, 38, 471-477. [CrossRef]

72. González Álvarez, M.; González-Barreiro, C.; Cancho-Grande, B.; Simal-Gándara, J. Relationships between Godello white wine sensory properties and its aromatic fingerprinting obtained by GC-MS. Food Chem. 2011, 129, 890-898. [CrossRef] 